\title{
Soil Management for Optimized Productivity Under Rainfed Conditions in the Semi-Arid Tropics ${ }^{1}$
}

\author{
S.A. El-Swaify, P. Pathak, T.J. Rego, and S. Singh*
}

\section{Contents}

I. Introduction

II. Soils of the Semi-Arid Tropics

III. Major Characteristics of SAT Vertisols and Alfisols

A. Vertisols

B. Alfisols

IV. Dryland Management Options for SAT Vertisols and Alfisols $\quad 14$

A. Vertisols 16

1. Traditional Use and Management

2. Improved Management for Optimized Resource Utilization and Increased Productivity

a. Physical Components

b. Fertility Components

c. Biological Components

3. Quantifying the Benefits of Improved Management 32

B. Alfisols

1. Traditional Use and Management

2. Components of Improved Management for Optimized Productivity

a. Physical Components 37

b. Fertility Components 48

c. Biological Components 54

V. Conclusions

References

\section{Introduction}

The semi-arid tropics (SAT) are defined in the context of Troll's (1965) vegetation zone delineation as the region within the tropics where the mean

1. Journal Article No. JA 383, International Crops Research Institute for the Semi-arid Tropics (ICRISAT), Hyderabad, A.P., India.

*Principal Soil Scientist, Agricultural Engineer, and Soil Scientists, respectively, Farming Systems Research Program 
monthly rainfall exceeds mean potential evapotranspiration during 2 to 7 months of the year. Within this region the areas where this excess lasts for 2 to 4.5 months are characterized by thorn Savannah vegetation and those where it lasts for 4.5 to 7 months are characterized by dry Savannah; these are called the dry SAT and wet-dry SAT, respectively.

Using this definition, the SAT comprise all or part of 48 countries on four continents (Figure 1, Table 1). Of these countries all but Australia are less developed. The region covers much of the African continent stretching in a broad band from west to east below the Sahara desert, and including much of eastern and south-central Africa. In Asia it includes most of India (which contains the single largest SAT area of any country, nearly $9 \%$ of the global total), northeastern Burma, and Thailand. Most of northern Australia, nearly all of Mexico, and large portions of Venezuela, Guyana, Surinam, French Guinea, Brazil, Paraguay, and Bolivia also lie within this region (Swindale, 1982).

The total area of the SAT is estimated at about 19.6 million $\mathrm{km}^{2}$ (Ryan, 1974). Here, more than 700 million, mostly impoverished, people live at an average population density of 0.34 persons/ha. However, density varies greatly in different countries so that in India it is almost five times the SAT average, while in Nigeria it is nearly twice (Ryan and Binswanger, 1979).

The important staple crops in the semi-arid tropics are sorghum (Sorghum bicolor (L.) Moench), pearl millet (Pennisetum americanum (L.) Leeke), pigeonpea (Cajanus cajan (L.) Millsp.), chickpea (Cicer arietinum L.), and groundnuts (Arachis hypogaea L.). According to Kanwar (1979), about $44 \%, 55 \%, 90 \%, 96 \%$, and $67 \%$ of these crops, respectively, are produced and consumed directly as human food thus serving as the main source of carbohydrate, protein, and fat for people living in the SAT.

Perhaps the most critical characteristic of the SAT from the agriculcural utilization viewpoint is the definite seasonality of rainfall; monsoon patterns prevail over much of the region. Nearly $90 \%$ of the rainfall is received during the summer: April to October in the northern hemisphere, and October to April in the southern hemisphere (Krishnan, 1975). While rainfall seasonality seems clearly predictable, actual precipitation varies widely among various SAT locations and from year to year so that $\mathrm{CV}$ values of $30 \%$ or more are not uncommon (e.g.. Figure 2). This variability also extends to

Table 1. Distribution of SAT within Different Continents

\begin{tabular}{lc}
\hline Region & \% of total SAT area \\
\hline West Africa & 24 \\
East Africa & 18 \\
South Africa & 20 \\
Latin America & 17 \\
Australia & 10 \\
South East Asia (mostly India) & 11 \\
\hline
\end{tabular}

Source: Derived from Ryan et al. (1974). 


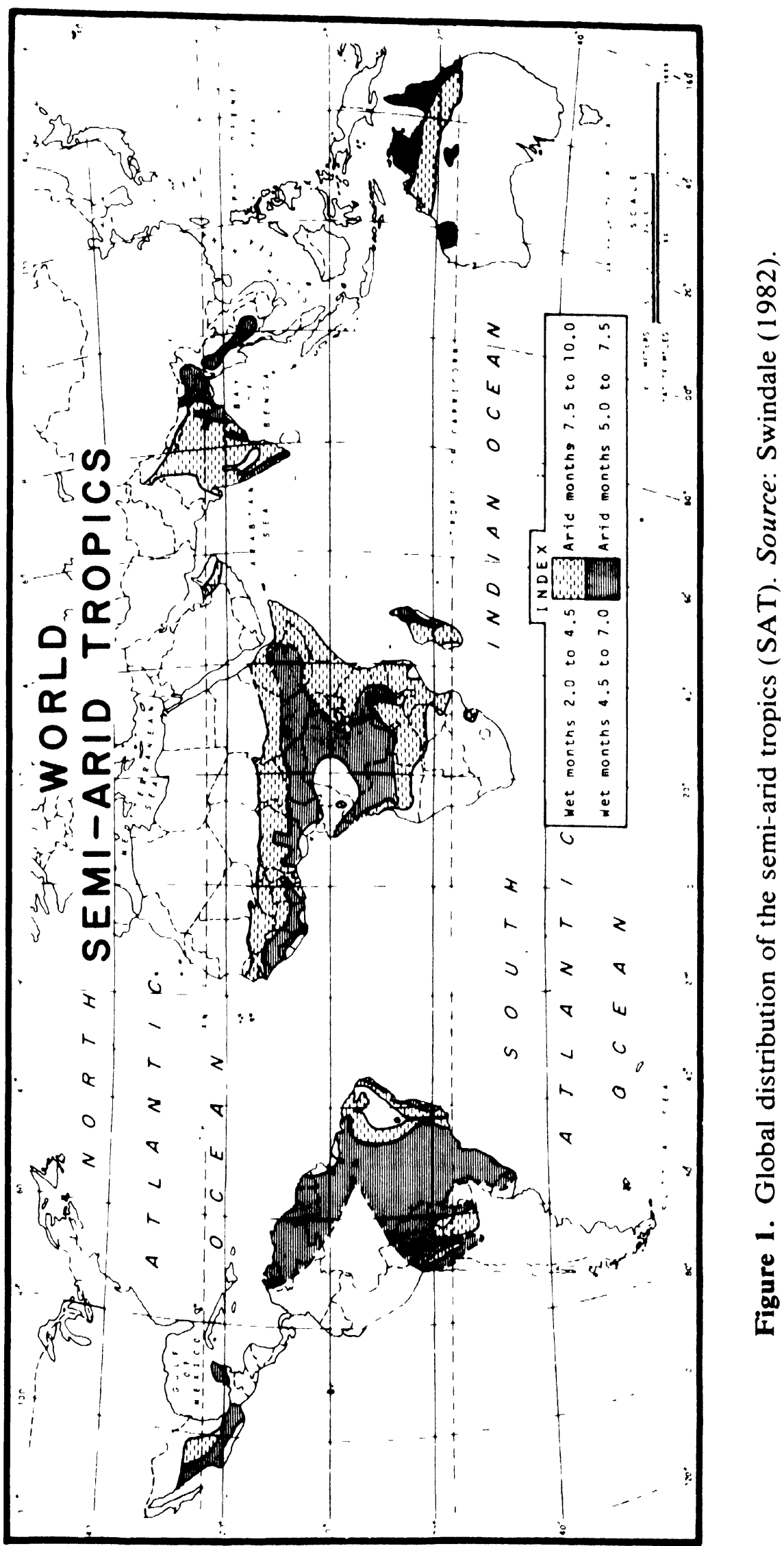




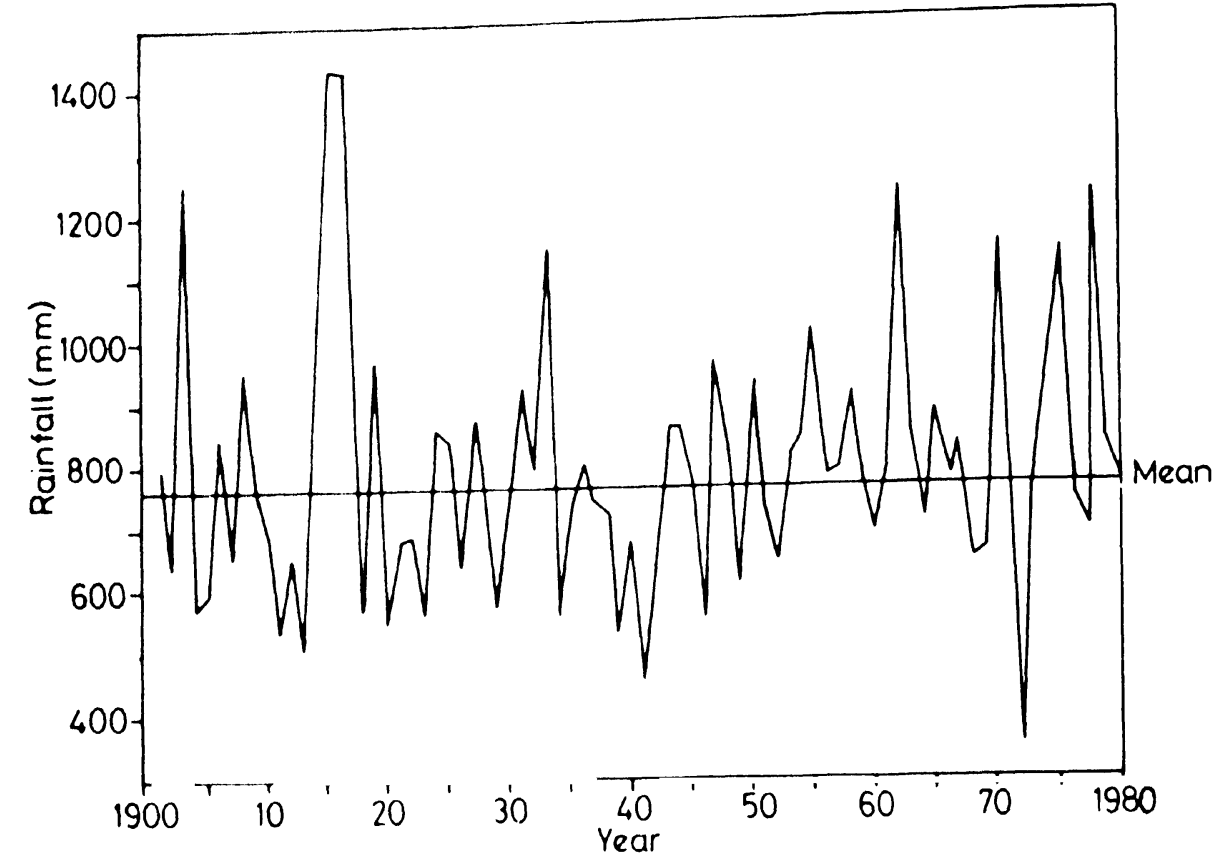

Figure 2. Annual rainfall totals at Hyderabad. India, during the period 19011980. Source: Virmani el al. (1980), updated.

the dates for rainfall arrival and withdrawal as well as its distribution within the rainy season (Figure 3). Figure 3 also shows the clear heterogeneity in spatial rainfall (and potential evapotranspiration) patterns in various SAT locations. Individual storm characteristics are also quite variable but, as a rule, a substantial portion of the total annual rainfall is accounted for by a few large, often intense, and highly erosive storms. For this, and other related reasons. SAT regions are generally considered to be of high potential erosion hazard (El-Swaify et al., 1982).

While winter rainfall is generally quite small, it can have a bearing on the yields of crops present then and the timing of various management practices such as land preparation before the main rainfall season. However, for rainfed agriculture, primary consideration is given to the duration of the effective rainfall period (and subsequently available soil water) which determines the successful establishment and sustainment of the cropping systems.

The highest temperatures in the SAT are generally attained just before the onset of the rainy season (Table 2). Prevailing temperatures and the fact that the mean annual values for solar radiation generally vary between 16 and $21 \mathrm{MJ} / \mathrm{M}^{2} /$ day (Landsberg et al., 1963: Thompson, 1965) indicate that the SAT environments possess a high potential for year-round cropping. Actual utilization of this potential, however, is restricted by water unavailability during the non-rainy season. On certain soils, such as deep Vertisols, in situ profile storage is a reliable source of water during the rainy season and for extending the cropping period into the post-rainy season. For others, such as shallow Alfisols, profile water storage is so limited that supplemental 


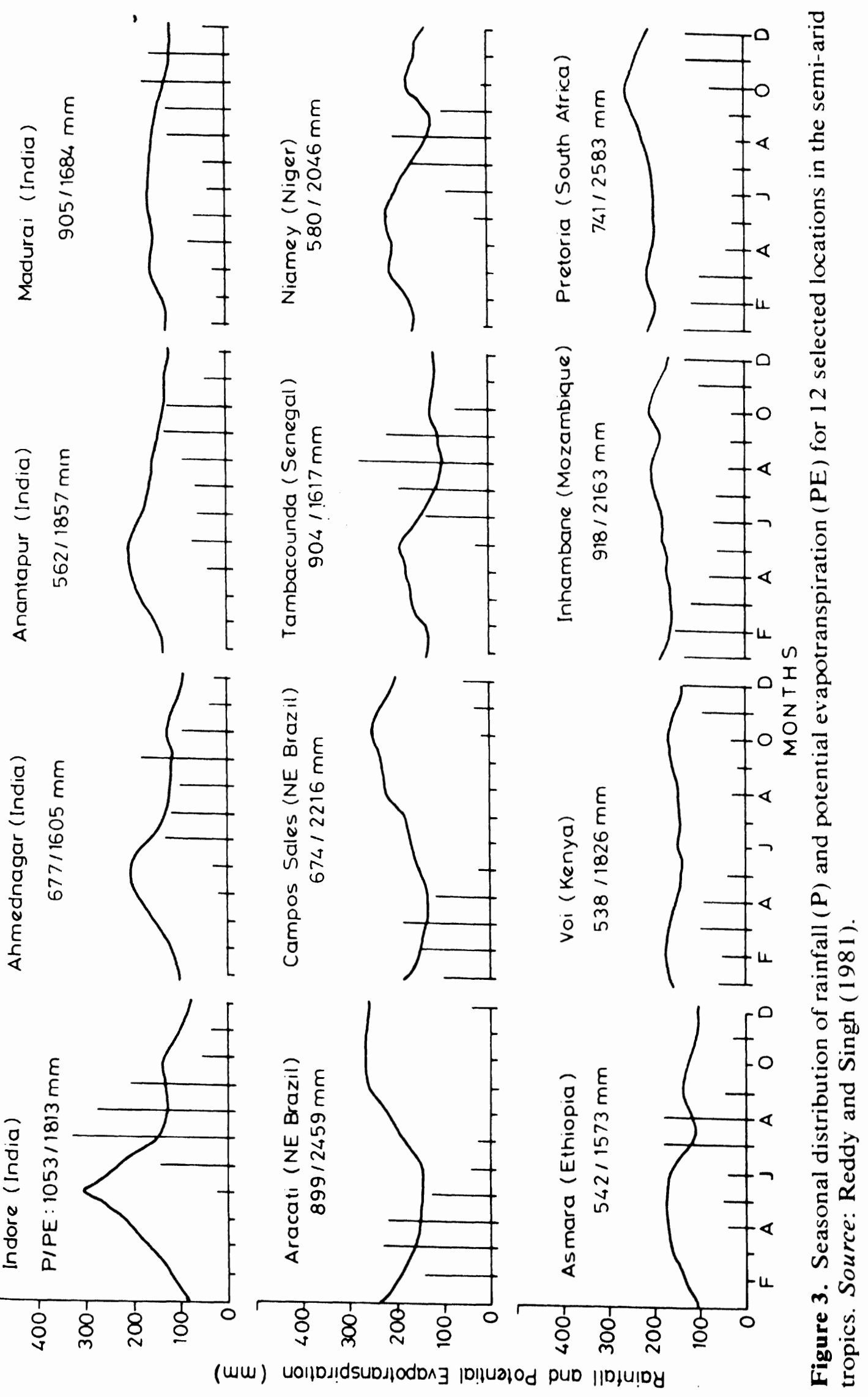




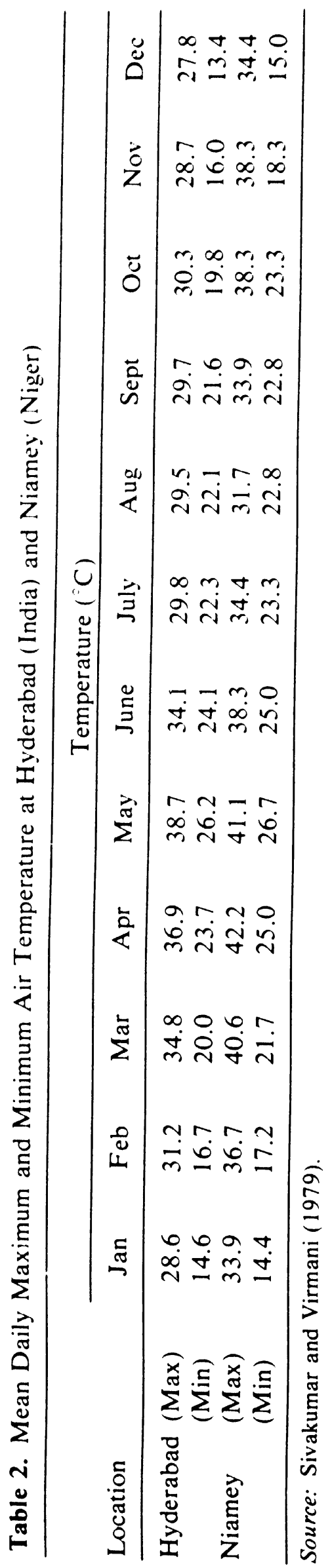


irrigation is necessary after the rainy season and, indeed, frequently even during dry spells within the season. In any case, understanding the nature and characteristics of soils in the SAT is critical to formulating a successful strategy for their use and management under rainfed conditions.

\section{Soils of the Semi-Arid Tropics}

The diversity of soils in the SAT is clearly indicated by the fact that eight of the ten orders in Soil Taxonomy (Soil Survey Staff, 1975) are represented in this region. Table 3 shows that nearly $68 \%$ of the land area is dominated by five of these orders, namely Alfisols $\left(6.94 \mathrm{~m} \mathrm{~km}^{2}\right)$. Aridisols $\left(5.2 \mathrm{~m} \mathrm{~km}^{2}\right)$, Entisols $\left(2.7 \mathrm{~m} \mathrm{~km}^{2}\right)$, Oxisols $\left(1.88 \mathrm{~m} \mathrm{~km}^{2}\right)$, and Vertisols $\left(1.31 \mathrm{~m} \mathrm{~km}^{2}\right)$. Within these orders, SAT environments are identified at the sub-order level w'titin the "ustic" moisture regime. This term implies dryness during parts of the year but "moisture is present at a time when conditions are suitable for plant growth" (Soil Survey Staff, 1975). The ustic regime is typical of tropical regions with a monsoon climate that has at least one rainy season lasting 3 months or more in a year.

In general, there is no direct correspondence between the orders in Soil Taxonomy and the soil map units adopted in the FAO/UNESCO soil maps of the world (FAO/UNESCO, 1974-78). According to the latter, however, the major soils of the SAT are the Acrisols (10\%), Arenosols (11\%), Ferralosols (33\%), Luvisols (15\%), Vertisols (7\%), and miscellaneous soils (Swindale, 1982). All are used for agricultural production under a wide variety of "traditional", "improved", or "developed" practices. These, together with general reviews of soil resources in the tropics and the SAT, have been given by Sanchez (1976) and Swindale (1982). The major

Table 3. Soils of the Semi-Arid Tropics

Area (million $\mathrm{km}^{2}$ )

\begin{tabular}{lcccc}
\cline { 2 - 5 } Soil order & Africa & Latin America & Asia & Total \\
\hline Alfisols & 4.66 & 1.07 & 1.21 & 6.94 \\
Aridisols & 4.40 & 0.33 & 0.47 & 5.20 \\
Entisols & 2.55 & 0.17 & - & 2.72 \\
Inceptisols & 0.38 & - & 0.28 & 0.66 \\
Mollisols & - & 0.78 & - & 0.78 \\
Oxisols & 1.88 & - & - & 1.88 \\
Ultisols & 0.24 & 0.08 & 0.20 & 0.52 \\
Vertisols & 0.51 & - & 0.80 & 1.31 \\
Others & - & 0.70 & 0.23 & 0.93 \\
Total & 14.62 & 3.13 & 3.19 & 20.94 \\
\hline
\end{tabular}

Source: Kampen and Burford (1980). 
characteristics of Alfisols, Ultisols, and Oxisols were provided by several authors in a recent monograph on soils with variable charge (Theng, 1980). These inventories, however, do not specifically document the vast experiences which have been acquired in recent years on the major constraints on productivity and the optimized management of various soils in the SAT. Of these we have selected Vertisols and Alfisols as case studies to illustrate the state-of-the-art of optimized soil management under rainfed SAT conditions.

Vertisols and Alfisols are not only clearly contrasting soils but research on their effective utilization has also had varying degrees of success. Both orders are represented within the experimental farm of the International Crops Research Institute for the Semi-Arid Tropics (ICRISAT Center). The two specific soil series at the farm, therefore, will be central to our subsequent discussions. Available information from other locations in the SAT will be presented where relevant.

\section{Major Characteristics of SAT Vertisols and Alfisols}

\section{A. Vertisols}

Vertisols are the deep (often several meters) black soils, generally called Black Cotton Soils, which are abundant in India, Sudan, Ethiopia, Australia, the U.S., and several other countries. Their primary diagnostic features include profile inversion and the development of deep and wide cracks which form upon drying and may be several $\mathrm{cm}$ wide and down to $1 \mathrm{~m}$ deep or more, reflecting substantial shrinkage. Such cracks remain open for 3-5 months or more and close only when the soil re-swells with sufficient wetting; in unirrigated SAT Vertisols (Usterts) this normally occurs several weeks after the onset of the rainy season. The abundance of cracks is responsible for high initial infiltration rates in dry Vertisols (as much as $100 \mathrm{~mm} / \mathrm{hr}$ ); the rates in the saturated soils are extremely low $(0.2 \mathrm{~mm} / \mathrm{hr})$. Self-mulching of surface layers may be responsible for covering soil cracks but that is not the case in all Vertisols. Often the soils are characterized by gilgai micro-relief which undergoes periodic changes with variations in the soil moisture regime. Gilgai relief is often obscured by cultivation such as in the Gezira area of Sudan (Finck. 1961). The structural development of the upper $40 \mathrm{~cm}$ of the profile is generally prismatic. separating to subangular to angular blocky peds with shiny pressure faces. The bulk density varies widely with time due to swelling and shrinkage. Bulk densities of $1.8 \mathrm{~g} / \mathrm{cm}^{3}$ or more are common for dry soils and $1.00 \mathrm{~g} / \mathrm{cm}^{3}$ or less for wet (swollen) soils. These values, when adjusted to a standard water content (field capacity), generally range between 1.6 and $1.8 \mathrm{~g} / \mathrm{cm}^{3}$ and increase with depth and overburden.

Vertisols are heavy in texture as they, by definition, contain more than $30 \%$ clay-sized particles. Texture is more or less uniform throughout the 
profile because of their "inversion" nature. Still, deeper layers may be higher in clay content than surface layers.

Vertisols may be derived from a variety of parent materials. Murthy et al. (1982) reported that the soils may be derived from basalt, shales, limestone, volcanic rocks, tuffs, gneisses, schists, and basic alluvium or colluvium materials. Most of the soil clay is of the swelling 2:1 lattice type: montmorillonite is often reported as the dominant clay mineral. For example, the clay fraction in Sudanese Vertisols contains more than $90 \%$ montmorillonite (Jewitt et al., 1979). Indian as well as Ethiopian Vertisols also have montmorillonite as the dominant clay mineral (De Vos and Virgo. 1969; Chatterjee and Rathore, 1976); the same is true for Vertisols in the

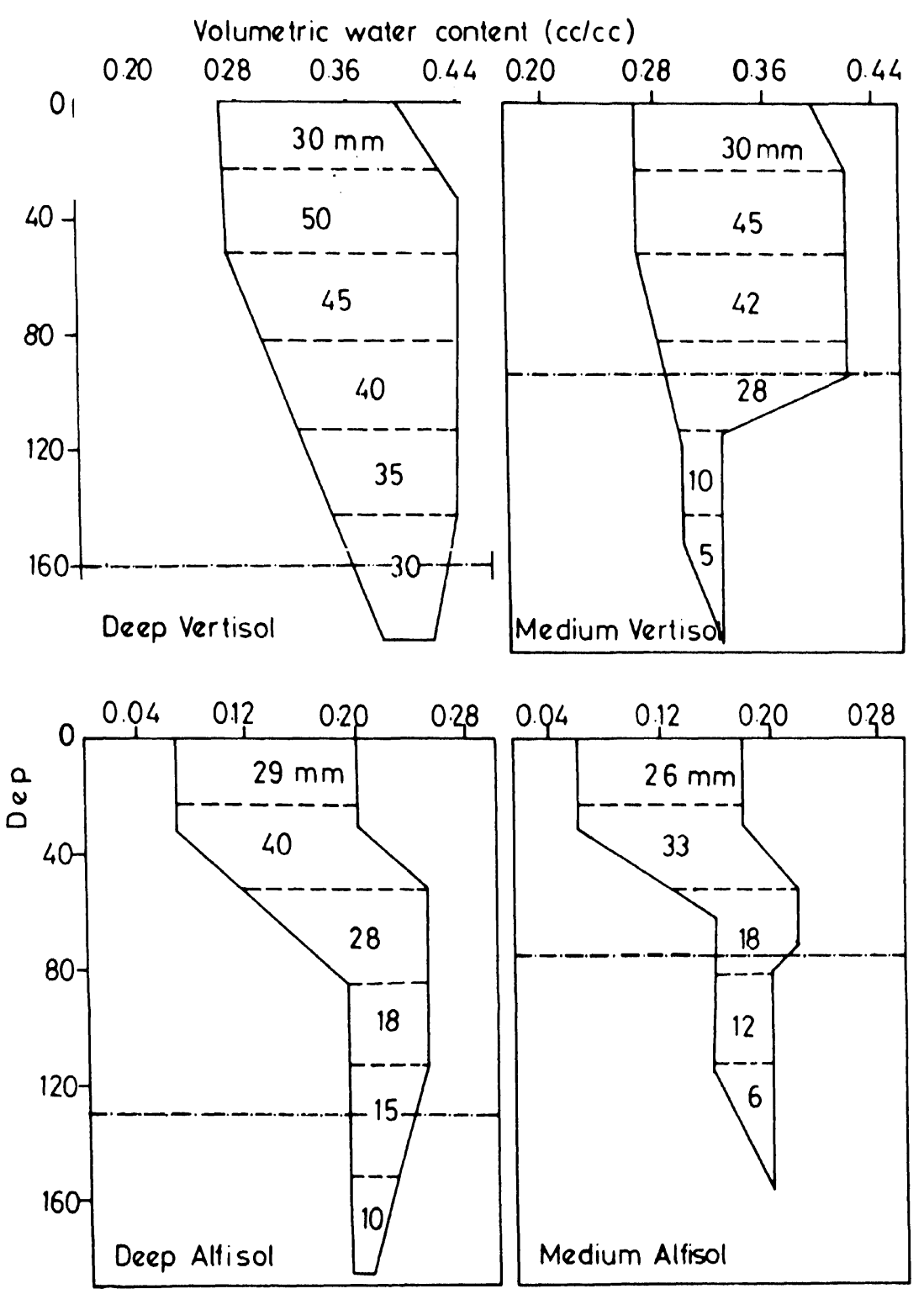

Figure 4. Available water profiles for deep $(>1 \mathrm{~m})$ and medium $(1 \mathrm{~m}-0.5 \mathrm{~m})$ Vertisols and Altisols at ICRISAT Lenter, Hyderabad, India. The dashed lines (--) represent the approximate lower end of the soil layer or the top of the "murrum" layer. 
Table 4. Major Characteristics of the Kasireddipalli Soil Series, a Typic

\begin{tabular}{lccccc}
\hline & \multicolumn{5}{c}{ Distribution (\%) of $<2 \mathrm{~mm}$ particles } \\
\cline { 3 - 6 } & & Coarse & & & \\
Depth & $\begin{array}{c}\text { sand } \\
\text { Horizon }\end{array}$ & Fine sand & Silt & Clay \\
& $(\mathrm{cm})$ & $(2.0-0.2)$ & $(0.2-0.02)$ & $(0.02-0.002)$ & $(<0.002$ \\
\hline AP & $0-16$ & 18.3 & 25.3 & 16.3 & 40.1 \\
B 12 & $16 \cdots 57$ & 17.6 & 15.6 & 17.3 & 49.5 \\
B 13 & $57-118$ & 8.9 & 10.0 & 20.4 & 60.7 \\
B 14 & $118 \cdots 115$ & 9.9 & 10.4 & 19.4 & 60.3 \\
\hline
\end{tabular}

\begin{tabular}{|c|c|c|c|c|c|c|c|}
\hline \multirow{2}{*}{$\begin{array}{l}\text { Depth } \\
(\mathrm{cm})\end{array}$} & \multicolumn{5}{|c|}{ Exchangeable cations (meq $100 \mathrm{~g}$ ) } & \multirow{2}{*}{$\begin{array}{c}\mathrm{CEC} \\
\mathrm{NH}_{4} \mathrm{OA}_{\mathrm{c}} \\
\text { (meq } 100 \mathrm{~g} \text { ) }\end{array}$} & \multirow{2}{*}{$\begin{array}{l}\text { Exchangeabl } \\
\text { sodium }(\%)\end{array}$} \\
\hline & $\mathrm{Ca}$ & $\mathrm{Mg}$ & $\mathrm{Na}$ & $\mathrm{K}$ & Sum & & \\
\hline 016 & 24.5 & 3.4 & 4.0 & 0.7 & 32.6 & 34.9 & 11 \\
\hline 16.57 & 23.9 & 3.2 & 5.4 & 0.6 & 33.1 & 35.2 & 15 \\
\hline $57 \cdot 118$ & 22.7 & 14.5 & 6.3 & 0.8 & 44.3 & 48.3 & 13 \\
\hline $118 \quad 155$ & 22.2 & 14.5 & 7.6 & 0.8 & 44.9 & 43.6 & 17 \\
\hline
\end{tabular}

"Values in parentheses are particle diameters $(\mathrm{mm})$.

${ }^{b} \mathrm{Am}$ amphibole; $\mathrm{KK}$ - kaolinite; $\mathrm{MI}=$ mica: $\mathrm{SM}=$ Smectite; $\mathrm{QZ}=$ quartz: $\mathrm{FDM}=$ feldspar microcline; FIDP feldspar plagioclase; $F M=$ ferromanganesium minerals; $F E=$ magnetite.

northern (tropical) environments of Australia (Norrish and Pickering, 1977). The high clay and montmorillonite contents impart considerable activity to these soils. Thus, the cation exchange capacity (CEC) in the Vertisols of India ranges between 47 and $65 \mathrm{meq} / 100 \mathrm{~g}$ (Roy and Barde, 1972) and in those of South Africa between 50 and $66 \mathrm{meq} / 100 \mathrm{~g}$. Calcium is the dominant natural cation on the exchange complex accounting for 52 to $85 \%$ of the total exchangeable ions. Magnesium ranges from 10 to $30 \%$ and sodium is usually less than $20 \%$ of total CEC.

Vertisols are physically quite responsive to changes in the chemical environment; the effects of exchangeable sodium depend upon the level of total soluble salts in the soil (El-Swaify et al., 1977). Vertisols containing very low contents of soluble salts can be detrimentally affected by as little as 6-8\% exchangeable sodium (Northcote, 1971). Under rainfed conditions, this remains a constant concern for Vertisols as the level of soluble salts is subject to large fluctuations and may be substantially reduced by seasonal rainfall. Appreciable contents of $\mathrm{CaCO}_{3}$ and $\mathrm{CaSO}_{4}$ are not uncommon in many Vertisols.

As these soils are deep and rich in swelling clays, their water storage capacity is relatively high. The average field capacity of a $185-\mathrm{cm}$ profile at 
Pellustert. at ICRISAT Center. Hyderabad. A.P.. India

\begin{tabular}{|c|c|c|c|c|c|c|c|c|c|c|}
\hline \multirow{2}{*}{$\begin{array}{l}\text { Coarse } \\
\text { fragments } \\
>2 \mathrm{~mm} \\
\text { (\% of } \\
\text { whole soil) }\end{array}$} & \multirow[b]{2}{*}{$\begin{array}{l}\text { Organic } \\
\text { carbon } \\
(\%)\end{array}$} & \multirow{2}{*}{\multicolumn{2}{|c|}{$\begin{array}{c}\text { Carbonate } \\
\text { as } \mathrm{CaCO}_{3} \\
(\%)\end{array}$}} & \multirow{2}{*}{\multicolumn{2}{|c|}{$\begin{array}{c}\mathrm{pH} \\
(1: 2.5) \mathrm{H}_{2} 0 \\
\text { suspension }\end{array}$}} & \multirow{2}{*}{\multicolumn{2}{|c|}{$\begin{array}{c}\mathrm{EC}(1: 2.5) \\
\mathrm{H}_{2} 0 \\
\text { suspension } \\
\text { (mmhos/cm) }\end{array}$}} & \multicolumn{3}{|c|}{ Water Retention } \\
\hline & & & & & & & & \multicolumn{3}{|c|}{$\begin{array}{l}\text { 1/3-bar 15-bar } \\
\text { (gravimetric \%) }\end{array}$} \\
\hline 10 & 0.27 & 1.1 & & & & & 10 & 32.5 & & 18.7 \\
\hline 18 & 0.12 & 1.1 & & & & & 20 & 34.9 & & 20.5 \\
\hline 3 & 0.18 & 1.4 & & & & & .25 & 33.4 & & 20.5 \\
\hline 20 & 0.12 & 2.2 & & & & & 30 & 35.8 & & 21.3 \\
\hline \multirow{2}{*}{$\begin{array}{l}\text { Base } \\
\text { saturation } \\
(\%)\end{array}$} & \multirow{2}{*}{$\begin{array}{c}\mathrm{CEC} / \text { clay } \\
\text { ratio }\end{array}$} & \multicolumn{4}{|c|}{$\begin{array}{l}\text { Clay fraction } \\
\text { mineralogy }\end{array}$} & \multicolumn{5}{|c|}{$\begin{array}{l}\text { Sand fraction } \\
\text { mineralogy }\end{array}$} \\
\hline & & $\mathrm{Am}$ & $\mathrm{KK}$ & MI & SM & QZ & FDM & FDP & FM & $\mathrm{FE}$ \\
\hline 93 & 0.87 & 4 & 1.4 & 7 & 64 & 5 & 10 & 55 & 10 & 20 \\
\hline 94 & 0.71 & 6 & 13 & 7 & 65 & 5 & 25 & 50 & 5 & 15 \\
\hline 92 & 0.80 & 5 & 13 & 7 & 68 & 5 & 10 & 55 & 5 & 20 \\
\hline $100+$ & 0.72 & 5 & 13 & 7 & 63 & 5 & 15 & 55 & 5 & 15 \\
\hline
\end{tabular}

ICRISAT Center is $810 \mathrm{~mm}$ and the lower limit of plant-available water is 590 $\mathrm{mm}$ (Russell, 1980). A two-meter deep profile, therefore, can hold more than $250 \mathrm{~mm}$ of plant-available water; similar data were reported by Stace et al. (1968) for Australian Vertisols. The distribution of extractable water in typical Vertisols profiles is shown in Figure 4 and Table 4.

Cultivation practices on Vertisols are particularly affected by the sticky nature, poor infiltration, and impeded internal drainage of the soils while wet, as well as excessive hardness and difficult workability while dry. Thus, cultivation practices must coincide with the specific range of soil water contents at which the soil is trafficable and of a consistency which allows easy preparation of the land and the production of good tilth.

Vertisols are moderately erodible soils; the universal soil-loss equation's $K$ values for many Vertisols have averaged at 0.3 on a scale of 0 to 0.69 for the lowest and highest observed erodibility, respectively (El-Swaify et al., 1982).

Other major characteristics of Vertisols have been given by various authors (e.g. Murthy et al., 1982). Table 4 summarizes the major properties of one Vertisol, the Kasireddipalli series, a Typic Pellustert, which will be the subject of much of our subsequent discussion on management options. 
that the soils are quite susceptible to erosion by water (El-Swaify and Dangler, 1982).

Much of the following discussion will be based on research with the Patancheru soil series, a Udic Rhodustalf at ICRISAT Center. Major characteristics of this soil are given in Table 5 .

It is important to note that while SAT Vertisols enjoy relative uniformity in their characteristics, Alfisols display a wide degree of diversity and spatial variability. Therefore. Table 4 may be more accepted as indicative of the properties of Typic Pellusterts than Table 5 is of those of Udic Rhodustalfs. Particular emphasis must be placed on the fact that soil classification in the SAT according to Soil Taxonomy still remains in a state of flux.

\section{Dryland Management Options for SAT Vertisols and Alfisols}

It is instructive at this point to introduce the seasonal division for SAT regions as summarized by Krantz et al. (1978). These authors defined three

Table 5. Major Characteristics of the Patancheru Soil Series, a Udic

\begin{tabular}{lcccc}
\hline & & \multicolumn{3}{c}{ Distribution $(\%)$ of $<2 \mathrm{~mm}_{\text {particles }}$} \\
\cline { 3 - 5 } Horizon & $\begin{array}{c}\text { Depth } \\
(\mathrm{cm})\end{array}$ & $\begin{array}{c}\text { Sand } \\
(2.0-0.2)\end{array}$ & $\begin{array}{c}\text { Silt } \\
(0.02-0.002)\end{array}$ & $\begin{array}{c}\text { Clay } \\
(<0.002)\end{array}$ \\
\hline AP & $0-5$ & 79.3 & 6.4 & 14.3 \\
B 1 & $5-18$ & 66.7 & 5.5 & 27.8 \\
B 21t & $18-36$ & 14.6 & 6.8 & 51.6 \\
B 22t & $36-71$ & 45.0 & 4.4 & 50.6 \\
B 23t & $71-112$ & 54.1 & 7.4 & 38.5 \\
B 3 & $112-140$ & 70.6 & 4.1 & 25.3 \\
\hline
\end{tabular}

\begin{tabular}{|c|c|c|c|c|c|c|c|}
\hline \multirow{2}{*}{$\begin{array}{l}\text { Depth } \\
(\mathrm{cm})\end{array}$} & \multicolumn{5}{|c|}{ Extractable bases (meq/100g) } & \multirow{2}{*}{$\begin{array}{c}\mathrm{CEC} \\
\mathrm{NH}_{4} \mathrm{OA}_{\mathrm{c}} \\
(\mathrm{meq} / 100 \mathrm{~g})\end{array}$} & \multirow{2}{*}{$\begin{array}{c}\text { Base } \\
\text { saturation } \\
(\%)\end{array}$} \\
\hline & $\mathrm{Ca}$ & $\mathrm{Mg}$ & $\mathrm{Na}$ & $\mathrm{K}$ & Sum & & \\
\hline $0-5$ & 2.6 & 0.5 & - & 0.4 & 3.5 & 4.8 & 74 \\
\hline $5-18$ & 3.8 & 0.9 & - & 0.5 & 5.2 & 8.2 & 64 \\
\hline $18-36$ & 5.8 & 3.8 & - & 0.6 & 10.2 & 14.8 & 69 \\
\hline $36-71$ & 7.9 & 3.1 & - & 0.6 & 11.6 & 14.1 & 82 \\
\hline $71-112$ & 5.4 & 2.5 & 0.3 & 0.4 & 8.6 & 9.8 & 88 \\
\hline $112-140$ & 5.7 & 1.9 & 0.5 & 0.3 & 8.4 & 9.1 & 92 \\
\hline
\end{tabular}

${ }^{a}$ Values in parentheses are particle diameters $(\mathrm{mm})$.

${ }^{b} \mathrm{Am}=$ amphibole: $\mathrm{KK}=$ kaolinite: $\mathrm{MI}=$ mica; $\mathrm{SM}=$ smectite; $\mathrm{QZ}=$ quartz; $\mathrm{FDM}=$ feldspar-microline: $\mathrm{FE}=$ Magnetite: $\mathrm{HE}=$ hematite: $\mathrm{FDP}=$ Feldspar-plagioclase. 
distinct periods which are agriculturally pertinent in the Hyderabad (India) area in particular and the SAT in general, the humid or monsoon season (100-110 days), the cool dry post-humid season (140-150 days). and the hot dry season (100-120 days).

The first period receives nearly $85 \%$ of the annual rainfall and, therefore, has the highest potential for crop production. It also has the highest erosion hazard due to rainfall concentration and the fact that the rainy season follows the hot-dry season during which vegetation growth is poor or absent and provides inadequate protection to the soil. Soils with good drainage, such as Alfisols, are normally cropped during this season. Poorly drained, heavytextured soils whose trafficability is poor while wet, such as Vertisols, are not normally cropped by many "traditional" farmers until the rainy season has been concluded.

The second, or post-rainy period receives little or no rain so that "rainfed" crop production is possible only on soils capable of storing sufficient profile water from the rainy season (such as Vertisols). Otherwise, crop production is possible only with supplemental irrigation.

The hot-dry period receives too little rainfall to allow sustained vegetative

Rhodustalf, at ICRISAT Center, Hyderabad, A.P., India

\begin{tabular}{|c|c|c|c|c|c|}
\hline \multirow{2}{*}{$\begin{array}{l}\text { Coarse } \\
\text { fragments } \\
>2 \mathrm{~mm}(\% \text { of } \\
\text { whole soil) }\end{array}$} & \multirow[b]{2}{*}{$\begin{array}{c}\text { Organic } \\
\text { carbon } \\
(\%)\end{array}$} & \multirow[b]{2}{*}{$\begin{array}{c}\mathrm{pH}(1: 2.5) \\
\mathrm{H}_{2} 0 \\
\text { suspension }\end{array}$} & \multirow{2}{*}{$\begin{array}{c}\text { EC }(1: 2.5) \\
\mathrm{H}_{2} 0 \\
\text { suspension } \\
(\text { mmhos } / \mathrm{cm})\end{array}$} & \multicolumn{2}{|c|}{ Water retention } \\
\hline & & & & $\begin{array}{l}\text { 1/3-bar } \\
\text { (gravimet }\end{array}$ & $\begin{array}{l}15-\text { bar } \\
\text { ic } \%)\end{array}$ \\
\hline 17 & 0.55 & 6.0 & 0.1 & 16.2 & 6.3 \\
\hline 17 & 0.52 & 6.9 & 0.1 & 20.0 & 12.4 \\
\hline 36 & 0.63 & 6.9 & 0.1 & 21.9 & 13.9 \\
\hline 54 & 0.40 & 6.8 & 0.1 & 24.8 & 17.4 \\
\hline 50 & 0.10 & 6.5 & 0.1 & 23.6 & 16.2 \\
\hline 63 & 0.18 & 6.2 & 0.2 & 18.7 & 11.5 \\
\hline
\end{tabular}

\begin{tabular}{|c|c|c|c|c|c|c|c|c|c|c|c|}
\hline \multirow{2}{*}{$\begin{array}{l}\mathrm{CEC} / \text { clay } \\
\text { ratio }\end{array}$} & \multicolumn{5}{|c|}{ Clay fraction mineralogy ${ }^{h}$} & \multicolumn{6}{|c|}{ Sand fraction mineralogy } \\
\hline & $\mathrm{Am}$ & KK & MI & SM & QZ & QZ & FDM & $\mathrm{FE}$ & $\mathrm{HE}$ & FDP & Others \\
\hline 34 & 11 & 37 & 12 & 17 & 17 & 35 & 25 & 10 & 10 & & 15 \\
\hline 29 & 12 & 37 & 10 & 19 & 14 & 45 & 20 & 5 & 5 & 10 & 15 \\
\hline 0.29 & 14 & 37 & 10 & 23 & 13 & 40 & 30 & 10 & - & 10 & 10 \\
\hline .28 & 12 & 38 & 11 & 20 & 16 & 30 & 30 & 5 & 5 & 15 & 15 \\
\hline 25 & 12 & 44 & 8 & 18 & 16 & 40 & 20 & 5 & - & 10 & 25 \\
\hline 0.36 & 10 & 39 & 8 & 21 & 16 & 35 & 25 & 5 & - & 15 & 20 \\
\hline
\end{tabular}


growth. From the management viewpoint, however, this meager rainfall may be sufficient for bringing the water contents of top soil layers up to a level which is suitable for performing the land preparations necessary for the upcoming rainy season. This period, due to characteristically low levels of biological activity, is also well-suited for "crop sanitation" and "insectsource reduction". Krantz et al. (1978) indicated that removal of all likely host plants for pests or pathogens during this period reduces their incidence of infestation in the subsequent cropping season.

Major variations occur in the climatic patterns of different SAT regions. However, the breakdown given above remains adequate to distinguish the overall seasonal patterns. In every case, cropping and soil management strategies must differ for different soils and cropping systems. These differences are well illustrated by the "traditional" uses and emerging technologies for improved utilization of Vertisols and Alfisols.

\section{A. Vertisols}

\section{Traditional Use and Management}

Traditional dryland farming systems on many, particularly deep, Vertisols involve leaving the land fallow during the rainy season and to main crop it only during the post-rainy season on profile-stored soil moisture. Fallow land is harrowed occasionally during the monsoon to control weeds; the practice may be aptly described as cultivated-fallow. In areas with low and relatively undependable rainfall (mean annual rainfall generally less than $750 \mathrm{~mm}$ ), this system has developed out of necessity because of the high risk of monsoon cropping and the likelihood of insufficient moisture to support both rainy season and the main post-rainy season crops. Kampen et al. (1974) made a distinction between "dry" and "wet" traditional monsoon fallow regions. Dry monsoon fallowing prevails where rainfall is erratic and too precarious to support a monsoon crop and is, therefore, a risk evasion measure (Binswanger et al., 1980). Wet monsoon fallowing is practiced where rainfall is adequate or excessive but monsoon cropping is risky from the standpoint of field flooding and waterlogging. Krantz and Quackenbush (1970). Krantz and Russell (1971), and Michaels (1982) quantitatively explained wet monsoon fallowing by the difficulty of preparing the hard dry soil prior to the monsoor or the sticky wet soil after its onset for the timely sowing and management of a crop, the common threat of flooding under heavy rains, and the possibility that monsoon cropping may still reduce soil moisture available for the post-monsoon crop to the point where yields are significantly reduced. Jodha (1979) further stressed that these soils are often difficult to work when dry or wet so that essential operations such as land preparation or weed control by manual labor are difficult to perform in the rainy season. The farmer has long recognized the high risks of growing a crop 
in the rainy season as compared to growing an assured post-rainy season crop on moisture that has already been safely stored in the soil profile.

The consequences of traditional rainy season fallowing in the dependable and high rainfall areas are serious both in terms of directly reduced land productivity and the frequent occurrence of excessive water losses as runoff and soil losses by erosion. If a crop is not grown in the rainy season the potential utilization of received rainfall (by a post-rainy season crop) is limited to the moisture storage capacity of the soil profile plus whatever little rainfall may occur in that season. Hydrologic studies of this traditional system have shown that of the total rainfall potentially available, about $28 \%$ is lost through runoff, $24 \%$ is lost through evaporation from the bare fallow soil, $9 \%$ is lost through deep percolation, and only $39 \%$ is actually utilized for evapotranspiration by a post-rainy reason sorghum crop (Table 6). These figures clearly illustrate that farmers who do not crop Vertisols during the rainy season not only lose the opportunity to benefit economically from an additional crop every year but also allow their fields to undergo substantial runoff and soil losses during that season. Krantz et al. (1978) argued that soil erosion due to rainy season fallowing is the reason why the proportion of Vertisols area classified as "deep" in the Sholapur district of India has shrunk from $46 \%$ to only $29 \%$ in a span of 75 years. Similarly, Dhruva Narayana and Ram Babu (1983) estimated that black-soil regions undergo the highest erosion rates in India at $64.5 \mathrm{Mg} / \mathrm{ha} /$ year.

The productivity of traditionally managed Vertisols is plagued by other problems. Where little or no fertilizer is applied, soil organic matter remains

Table 6. Estimated Soil Water Balance Components and Soil Loss Observed for the Traditional Rainy Season Fallow System on Vertisols at ICRISAT Center ${ }^{a}$

\begin{tabular}{lcccccc}
\hline Rainfall & $\begin{array}{c}\text { Runoff } \\
(\mathrm{mm})\end{array}$ & $\begin{array}{c}\text { Evaporation } \\
\text { (fallow } \\
\text { rainy } \\
\text { season) } \\
(\mathrm{mm})\end{array}$ & $\begin{array}{c}\text { Evapotrans- } \\
\text { piration } \\
\text { (cropped } \\
\text { post-rainy } \\
\text { season) }(\mathrm{mm})\end{array}$ & $\begin{array}{c}\text { Deep } \\
\text { percolation } \\
(\mathrm{mm})\end{array}$ & $\begin{array}{c}\text { Soil } \\
\text { loss } \\
(\mathrm{Mg} / \mathrm{ha})\end{array}$ \\
\hline 1976 & 710 & 238 & 169 & 272 & 31 & 9.20 \\
1977 & 586 & 53 & 201 & 317 & 15 & 1.68 \\
1978 & 1117 & 410 & 185 & 301 & 221 & 9.69 \\
1979 & 682 & 202 & 166 & 272 & 42 & 9.47 \\
1980 & 688 & 166 & 175 & 300 & 47 & 4.58 \\
$1976-$ & 100 & 28.2 & 23.7 & 38.5 & 9.46 & $6.93^{c}$ \\
$1980^{b}$ & & & & & & \\
\hline
\end{tabular}

${ }^{a}$ Traditional varieties of sorghum were grown as the post-rainy season crop.

${ }^{b}$ In percentage of rainfall

cAverage annual soil loss for the study period. 
the major source of crop nutrients (particularly $\mathrm{N}, \mathrm{S}$, and to some extent $\mathrm{P}$ ). Where economically justified, farmyard manure is applied every 2-4 years for certain crops. Thus cropped SAT Vertisols in general contain low amounts of organic matter $(0.3-2.0 \%)$ as shown in Table 4 . Since cultivation has replaced shifting agriculture in many SAT regions due to increasing population pressures, soil organic matter contents have declined at a steady rate. Aside from the high decomposition rates inherent to this climatic regime, the practice of removing crop residues for animal feed and other uses is common. Organic matter may be relatively less important in Vertisols than Alfisols as regards expanding the nutrient reservoir. However, organic matter is equally vital in both soils for promoting structural development (Biswas, 1982) and as a source of nutrients in limited-fertilizer agriculture. It is important to add here that while traditional rainy season fallowing may allow the buildup of small amounts of nutrients such as $\mathrm{N}$ by mineralization, it is harmful to soil fertility in the long run. Nutrients not captured by a growing crop during the rainy season are subject to a multitude of losses with runoff, eroded soils, or leaching.

Because of the above and due to the general lack of adequate seeds, use of inefficient farming implements, and other reasons which will become evident with the discussion of improved systems, it is not surprising that crop yields from traditionally cultivated Vertisols are very low. Actual surveys of annual yields from farmers' fields in selected villages of peninsular India have been reported (Kanwar et al., 1982) to be as follows:

Sorghum

Wheat (Triticum durum Desf.)

Chickpea

Safflower (Carthamus tinctorius L.)

Chillies, dry (Capsicum annuum L.)
$0.50-0.90 \mathrm{Mg} / \mathrm{ha}$

$0.30-0.70 \mathrm{Mg} / \mathrm{ha}$

$0.20-0.50 \mathrm{Mg} / \mathrm{ha}$

$0.30-0.50 \mathrm{Mg} / \mathrm{ha}$

$0.20-0.70 \mathrm{Mg} / \mathrm{ha}$

These levels sharply contrast with projected yields of up to $6 \mathrm{Mg} / \mathrm{ha}$ reported from research on several crops based on effective use of potentially available water (Kampen, 1982: Swindale, 1982). Low yields and the abovedescribed inefficient resource utilization clearly reflect the extremely low productivity of traditional cropping of SAT Vertisols. That improvements in all these facets are possible in order to realize at least part of the soils' potential productivity will be demonstrated in the following section.

\section{Improved Management for Optimized Resource Utilization and Increased} Productivity

Establishing a technology for cropping Vertisols during the rainy season (elimination of cultivated-fallow) has been the major thrust of research aimed at increasing the agricultural productivity of Vertisols under rainfed conditions. This was identified as an early target for farming systems research at ICRISAT, the International Crops Research Institute for the SemiArid Tropics (Binswanger et al., 1980). Recommended approaches for 
constructing improved technological packages have been formulated for Vertisols in the medium to high and dependable rainfall zones, i.e. those receiving $750^{\circ}-1250 \mathrm{~mm} /$ year with more than $70 \%$ probability that $10 \mathrm{~mm} /$ week of rain will be received during half the weeks of the rainy season (Virmani et al., 1978). These approaches, which heavily emphasize the needs of the small farmer in the SAT, are watershed-based, soil and water conservation-minded, and capitalize on a critical number of management components for optimizing agricultural productivity. These components may be conveniently divided into physical (including engineering and implement design requirements), chemical, and biological; all are discussed below in detail.

\section{a. Physical Components}

The primary purpose of these components is to optimize the physical environment in the field, to minimize runoff and erosion, and to ensure adequate water storage and aeration around the seeds and crop roots so as to allow the farmer to grow crops during both the rainy and post-rainy seasons. This involves combining deliberately timed operations for land preparation, primary tillage, seed bed design, seed and fertilizer placement, and runoff disposal and harnessing for reuse when needed for supplemental irrigation.

Land smoothing and installation of drains for effective surface drainage and runoff disposal from the field are the first steps emphasized in the ICRISAT approach. This is necessary because, in Vertisols, the overall macro-relief of major ridges and valleys on the land surface is frequently overlain by small differences in micro-relief which form depressions of various sizes with impeded surface drainage. During wet periods these depressions are subject to short-term waterlogging. Smoothing the land surface should be done, for greater efficiency, in the direction of cultivation envisaged for the field in question. It is not to be confused with general land leveling as it involves much less soil disturbance and is, therefore, relatively inexpensive to perform. The installation of provisions for the early and safe removal of excess runoff is necessary as the (assured) rainfall characteristics of most of the Vertisol regions under discussion are such that runoff will occur frequently. Installation of required waterways is often possible by improving the natural drains within the landscape by clearly delineating, shaping, and straightening them out. Where necessary, their longitudinal slopes should be adjusted such that they will be stable after a suitable grass cover has been provided. Recent experiences in India indicate that required steps can be effectively completed at reasonable cost while utilizing animal drawn implements and human labor. Costs of land development executed by CRISAT in collaboration with national research institutions on actual farmers' fields ranged from about US $\$ 20$ to $\$ 50$ per hectare, incurred only once. Exact costs depend upon the extent of required land smoothing, the number and size of needed field drains, and the implements used (Kampen, 1982). 
Installing a land configuration within the field which provides adequate (in situ) control of runoff and erosion, improves subsurface drainage for a favorable aeration status and workability of soil in the seed or root environment, and defines the traffic and cropping zones within the field is the second step of I'RISAT's improved technology for SAT Vertisols. A broadbed and furrow (BBF) system involving graded wide beds separated by furrows which drain into grassed waterways appears to fulfill these requirements satisfactorily. A schematic sketch of a representative BBF system and its layout within a self-contained catchment are shown in Figure 5. Successfully tested by I'RISAT both in research and operational scale studies at farmers' fields, this system consists of modules $150 \mathrm{~cm}$ wide. The flat bed or ridge and the furrow portions are 100 and $50 \mathrm{~cm}$ wide, respectively. The BBF system is laid out on a grade of 0.4 to $0.8 \%$ for optimum performance (Kampen, 1982). The raised bed portion acts as in

(a)
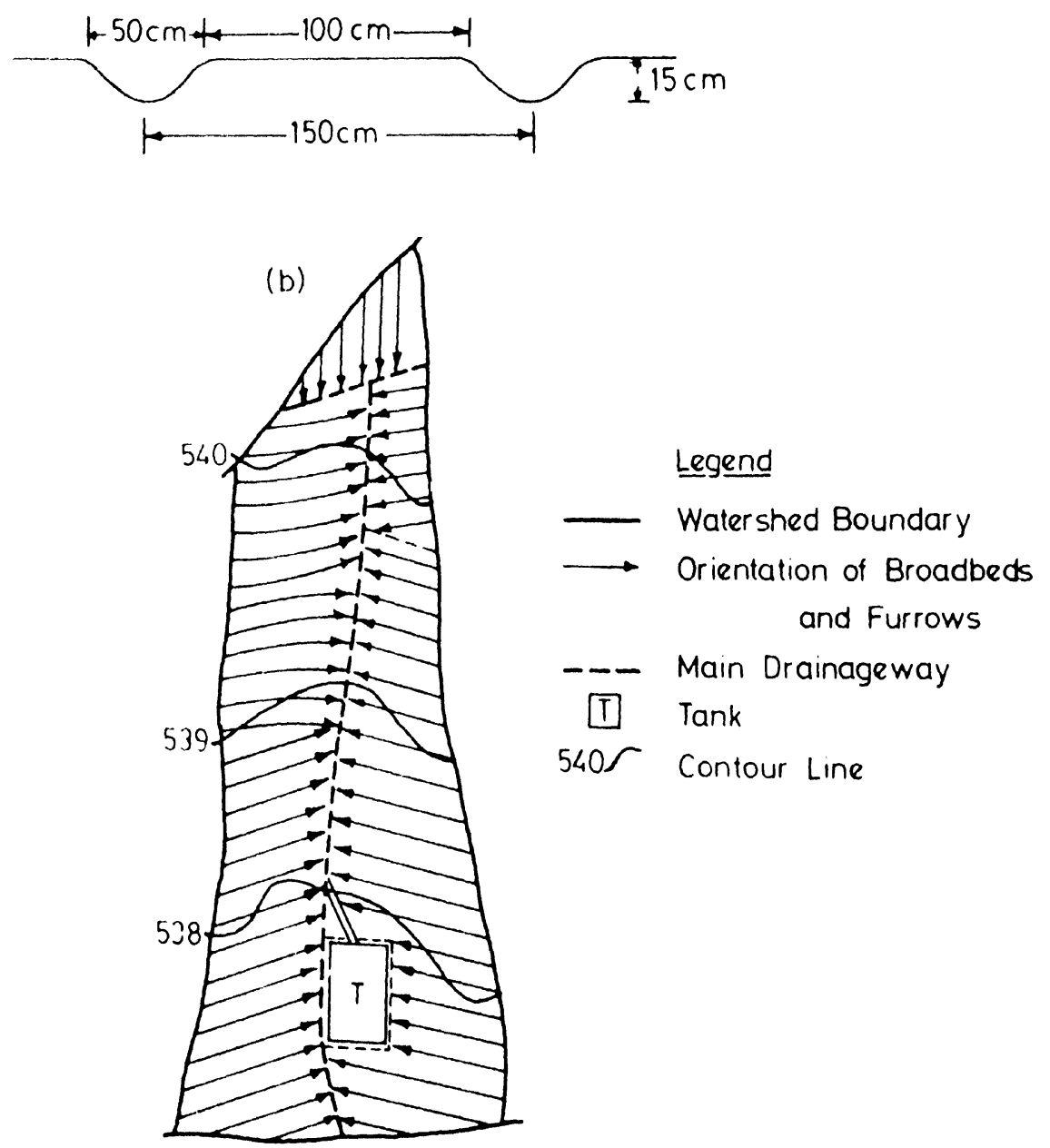

Figure 5. (a) A section of the broad bed and furrow (BBF) configuration recommended for improved management of Vertisols. (b) A schematic sketch of a watershed-based farm design for improved land and water management. The tank (T) is a small reservoir intended for storing excess surface runoff for use in supplemental irrigation. 
situ 'bund' to ensure soil stability and the shallow furrow $(15 \mathrm{~cm}$ deep) provides surface drainage to promote aeration and prevent waterlogging of crops growing on the bed. For Hyderabad, with a total annual rainfall of nearly $800 \mathrm{~mm}$, the maximum recommended furrow length along the slope is $100 \mathrm{~m}$.

The BBF design is quite flexible for accomodating crops and cropping systems with widely differing row spacing requirements. For instance, maize ( 2 rows, $75 \mathrm{~cm}$ apart), sorghum or millet ( 3 rows, $45 \mathrm{~cm}$ apart), groundnuts ( 4 rows, $30 \mathrm{~cm}$ apart), and intercrops of sorghum or millet (two rows $90 \mathrm{~cm}$ apart) with pigeonpea (one row in the middle) all can fit conveniently on the bed portion of the BBF. Precision operations such as mechanical weeding and placement of seeds or fertilizers are facilitated by the defined traffic zone (the furrow) and specially designed field implements (discussed below), even when seed and fertilizer are applied separaiely. Furthermore, the system is easily used for application of supplemental irrigation water when necessary. Since animal equipment traffic is largely restricted to the furrow zone, soil compaction within the raised bed planting zone is minimized (Kampen, 1982). There is evidence that, when the sytem is maintained in place on a long-term basis, a progressive improvement in soil tilth occurs in the bed zone. For instance the penetration resistance in this zone was significantly lower than its counterpart in flat systems (Figure 6) (ICRISAT, 1981). This facilitates land preparation during the summer season and dry sowing of the rainy season crop; both are required steps in the improved technology. It also allows deep seed placement for adequate germination under receding moisture conditions when post-rainy season planting must be performed. Furthermore, air-filled porosity in the upper $15-\mathrm{cm}$ layer was found to be significantly higher for BBF than for the flat system during wet spells (Figure 7) (ICRISAT, 1981). This confirms the effectiveness of the BBF in improving the drainage in the seed and root environment of Vertisols.

Use of animal-drawn precision equipment is the third requirement for successful cropping in the rainy season. An animal-drawn wheeled tool carrier originally designed by Jean Nolle (ICRISAT, 1983) and now commercially available under various brand names, was found to be more efficient and precise than traditional implements in carrying out all the cultivation, sowing, fertilizing, and weeding operations specified under the BBF system (ICRISAT, 1981a). The recommended equipment (Figure 8) also offers considerable time savings to the farmer. Performing primary tillage with this equipment on a $150-\mathrm{cm}$ BBF system consumes only $10 \%$ of the time required for traditional cultivation. Experience has shown that success of the recommended technology in improving the farming systems on Vertisols hinges upon as rapid and efficient performance of required sperations as can be readily achieved with such a tool carrier or similar squipment.

The timing and mode of primary soil tillage are other critical physical :omponents for improved management of Vertisols (Kampen, 1982). In view 


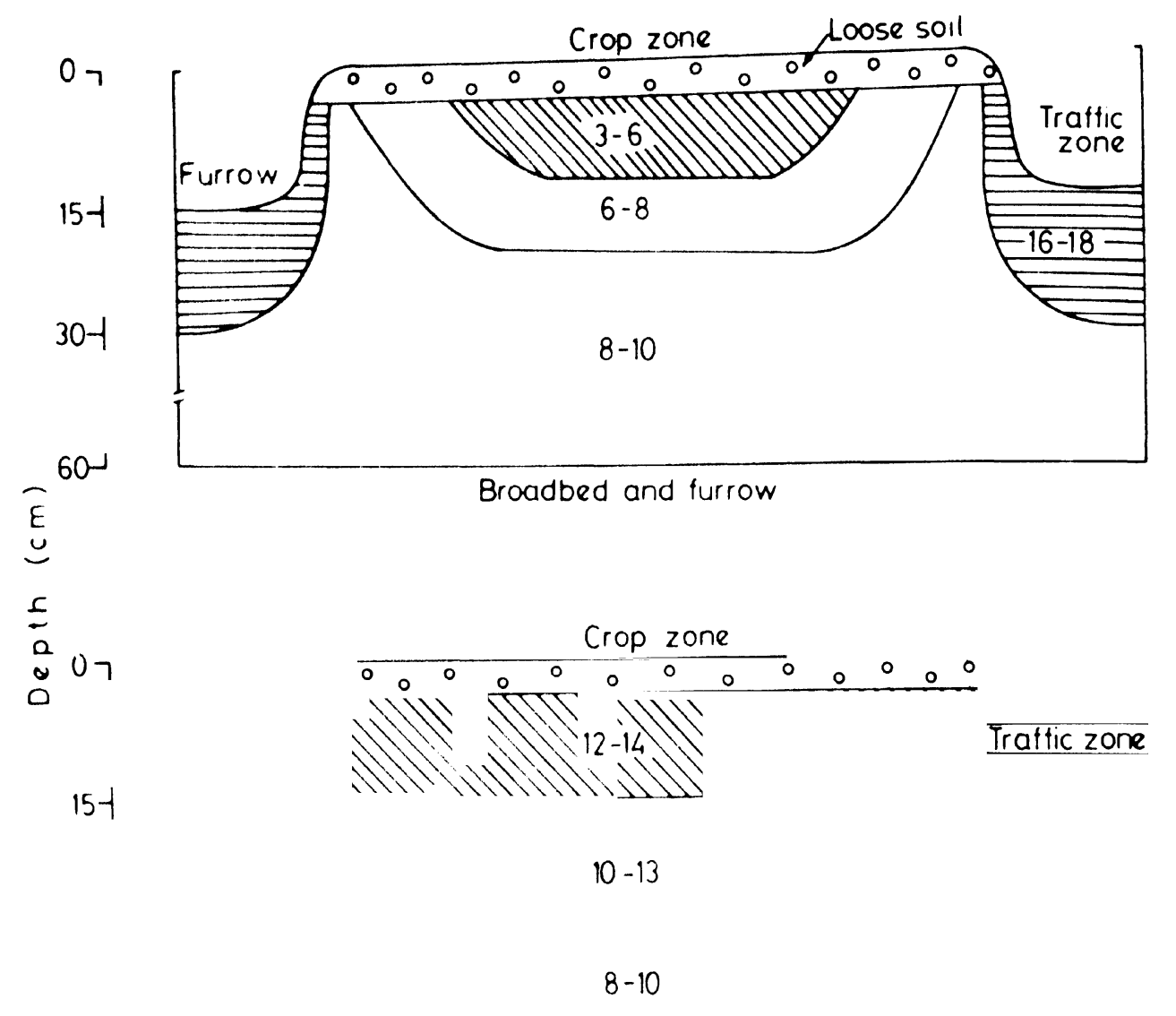

$60-$

Flat on grade

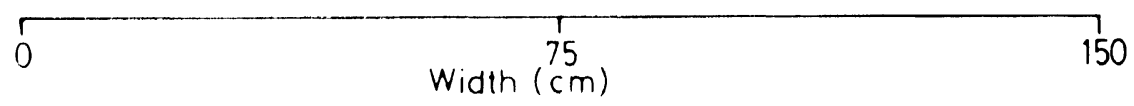

Figure 6. Penctration resistance zones (expressed in $\mathrm{kg} / \mathrm{cm}^{2}$ ) under broadbed and furrow and hat systems on Vertisols at ICRISAT Center, 1980/81. Gravimetric soil water contents were $24+1.9 \%, 31+2.4 \%$, and $33 \pm 2.9 \%$ for the $0-15 \mathrm{~cm}, 15-30$ $\mathrm{cm}$, and $3060 \mathrm{~cm}$ soil depths, respectively. Source: ICRISAT (1981).

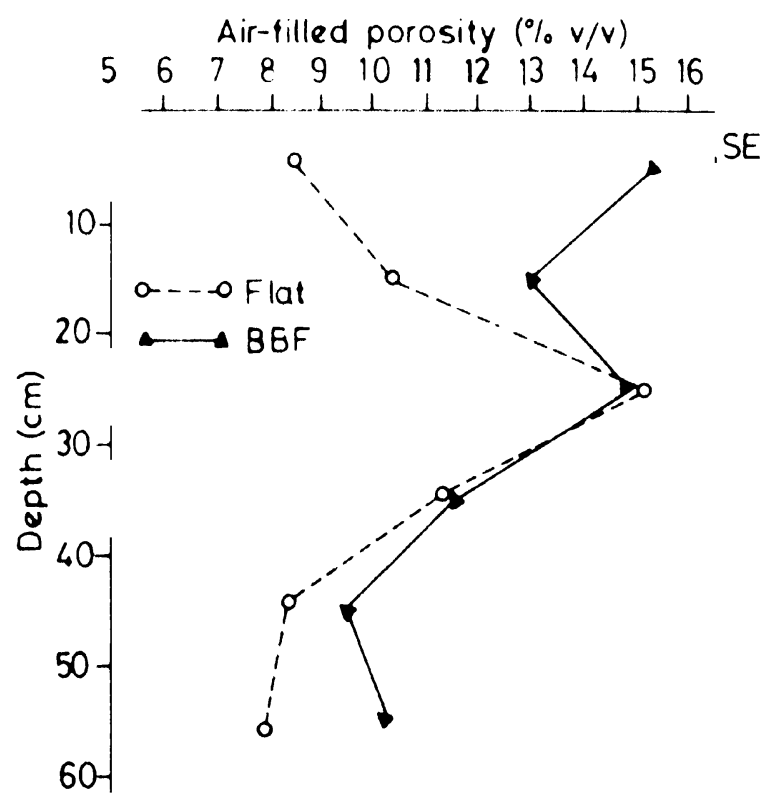

Figure 7. Air-filled porosity in Vertisols at ICRISAT Center during the high moisture period (late August-early September), 1980/ 81. Source: ICRISAT (1981). 
Figure 8. A commercial version of the wheeled tool carrier (marketed undęr the brand name Nikart) which is recommended for use in BBF culture. The basic unit consists of a frame mounted on two rubbertired wheels with a tool bar onto which a variety of implements can be attached. This version is equipped with a seedcum-fertilizer drill. Source: ICRISAT (1983).

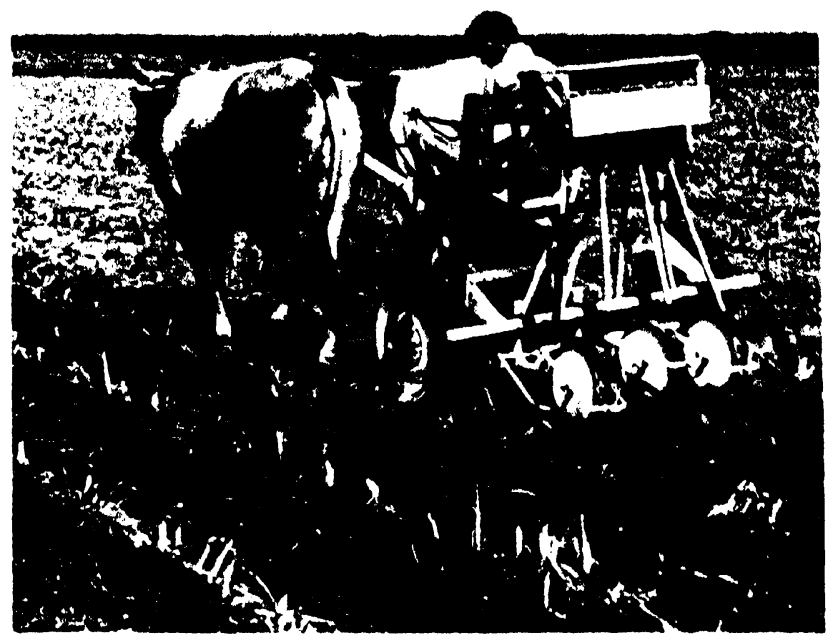

of the difficult workability of these soils both in the very dry and very wet conditions, the most suitable time to conduct primary tillage is immediately following the harvest of the post-rainy season crop. At this time, the soil water content is such that primary tillage can be performed rapidly and efficiently before the soil undergoes excessive drying with exposure to the hot and windy conditions of summer months. An added benefit of this timing is to prevent growing weeds from setting seeds, thus reducing weed problems during subsequent growth periods (Shetty et al., 1977). With the BBF system "permanently" in place, tillage operations in the bed zone become progressively easier from year to year (see Figure 6). Because of the high content of "active" layer silicates in Vertisols, soil structural buildup takes place quite readily as compared to, for instance, Alfisols (Charreau, 1977) so that the soils appear to have minimum need for intensive tillage. A satisfactory method which is now used routinely at ICRISAT makes use of right- and left-hand moldboard plows mounted simultaneously on the bullock-drawn wheeled tool carrier. The plows are set so as to turn the weeds 'and stubble from the just harvested crop over into the seed zones of the next crop. Generally the center of the bed is left in a cloddy condition so that the soil surface will be highly receptive to any dry-season rains. Final land preparation is initiated immediately following such rains so that the system is again ready for pre-monsoon sowing of the next year's crop.

Runoff harnessing, storage, and reuse for supplemental irrigation is the last physical feature of ICRISAT's watershed-based approach (Figure 5). Supplemental irrigation, when strategically timed during dry spells in the rainy season or used to extend the growing period into the post-rainy season, markedly decreases the risks involved in rainfed agriculture and improves land productivity. On Vertisols with dependable rainy season precipitation, the probability of moisture stress to the crop at critical growth stages during the monsoon is small. However, significant returns have been gained from the 


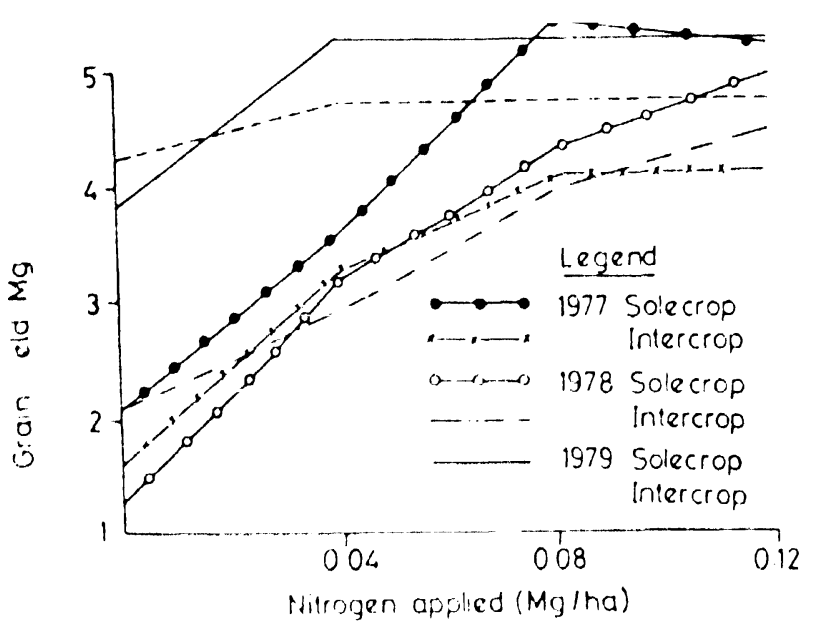

Figure 1.9. Response of sole crop and intercropped sorghum to nitrogen fertilization on Vertisols at ICRISAT Center (1977-1979). Source: ICRISAT (1981).

The yields were nearly equal in the second year. Assessment of the soil $\mathrm{NO}_{3}$ status indicated that the usual buildup of mineralized $\mathrm{NO}_{3}$ was of equal benefit to both crops in the normal rainfall year (1981), but was subject to excessive losses with heavy early monsoon rains in 1980 (unpublished results, Rego, 1983). One advantage of the dry sowing technique is allowing full utilization of the $\mathrm{NO}_{3}$ flush formed after the hot summer months. Clearly, cropping systems design and management have a strong bearing on the nitrogen balance in Vertisols. These will be further discussed in section IV.A.2.c.

Phosphorus appears to be the second most limiting nutrient to the fertility of SAT Vertisols. This is predictable from the fact that most contain only from 2 to $10 \mathrm{ppm}$ of available (Olsen extractable) P (unpublished data,

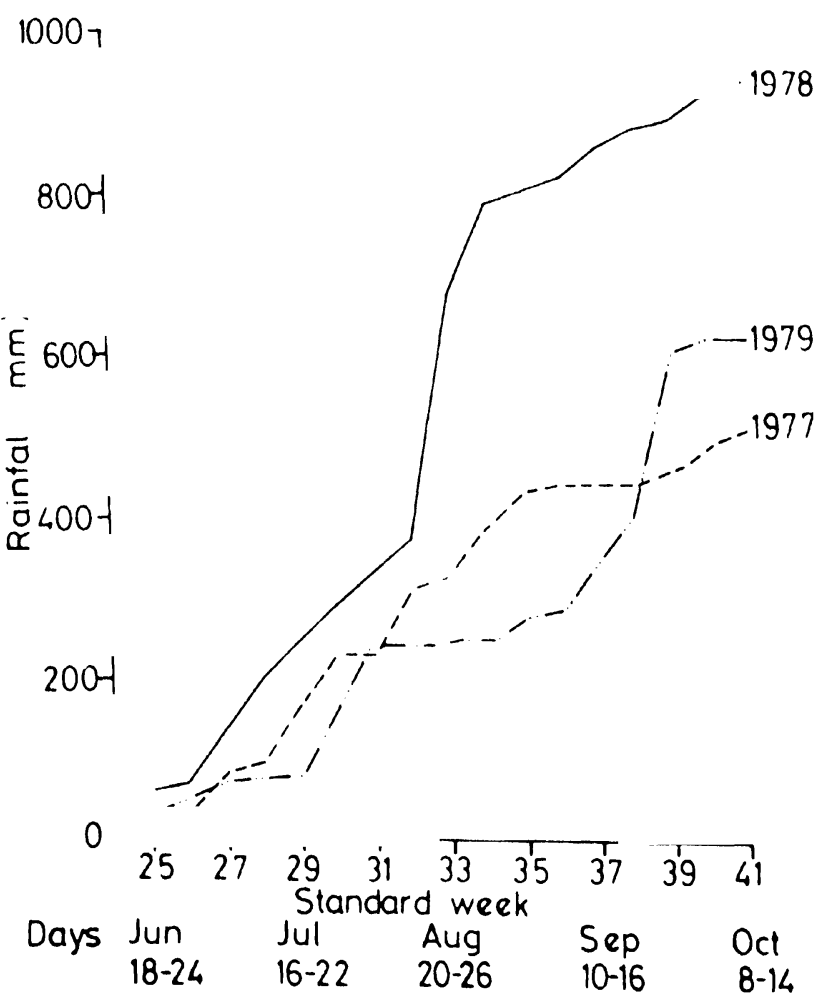

Figure 10. Kharif (rainy season) rainfall at ICRISAT Center during 1977-79. 
K.L. Sahrawat, ICRISAT, 1983). However, Venkateswarlu (1979) reported inconclusive response patterns for many crops to applied $\mathbf{P}$ under rainfed conditions (Table 8). These are typical of other published reports on these soils. Since Vertisols do not contain "P-fixing" clays, the availability of P is primarily hampered by its reacting with native $\mathrm{CaCO}_{3}$ to form relatively insoluble apatites. Venkateswarlu (1979) observed that, as for N.P availability was restricted by moisture deficiency in the post-rainy season. Where $\mathbf{P}$ fertilization was required for adequate yields, more responses were obtained with irrigation and higher rates of $\mathrm{N}$ fertilization. Recovery of added $P$ is further enhanced by placement in bands to reduce the contact between fertilizer and soil, particularly where fixation or precipitation are likely. The application of $20 \mathrm{Kg}$ as $\mathrm{P}$ per ha is recommended as a component of the improved production technology on Vertisols.

Potassium fertilization is not normally required for rainfed Vertisols, as the soils are rich in native $\mathrm{K}$ (Table 4 ). With traditional practices, micronutrient deficiencies are also seldom noted because of low yields. However, with the introduction of high-yielding cultivars, these elements are depleted from soil at a faster rate. Therefore, increased incidence of $\mathrm{Zn}$ and $\mathrm{S}$ deficiencies and calcium-induced $F \mathrm{e}$ chlorosis have been reported (Rao and Das, 1982; Finck and Venkateswarlu, 1982). Micronutrient applications may become important in the future should adoption of high-yielding varieties with improved technology proceed at a rapid pace.

Table 9 summarizes the fertilization strategies recommended for major limiting nutrients on these soils. Also related to fertility factors are occasional salinity and sodicity problems which are encountered in some SAT Vertisols. Under rainfed conditions these problems often appear to be transient or easily correctable by standard management techniques and application of organic or inorganic amendments.

\section{c. Biological Components}

Sowing techniques, crop and cultivar selection, cropping systems design, crop residue manipulation, pest control, and related management elements have a major bearing on improving the productivity of Vertisols. Biological factors can be potentially most restrictive to double-cropping strategies in view of the limited time available to conduct required operations. Dry sowing ahead of the rainy season, therefore, is an important component of ICRISAT's recommended rainy season cropping. Sowing and application of chemical fertilizers become difficult on Vertisols once the rains have set in and the soils have become wet. Delayed sowing is also undesirable because it shortens the effective growing period and increases the probability of pest attacks on some crops, e.g. the shootfly [Atherigona soccata (Rondani)] on sorghum. However, the success of dry sowing practices is clearly dependent on the pattern and dependability of rainfall early in the monsoon. Early rains that are fairly dependable and follow-up rains that are reliable are needed to ensure the establishment of the germinating crops (Virmani, 1980). Studies 


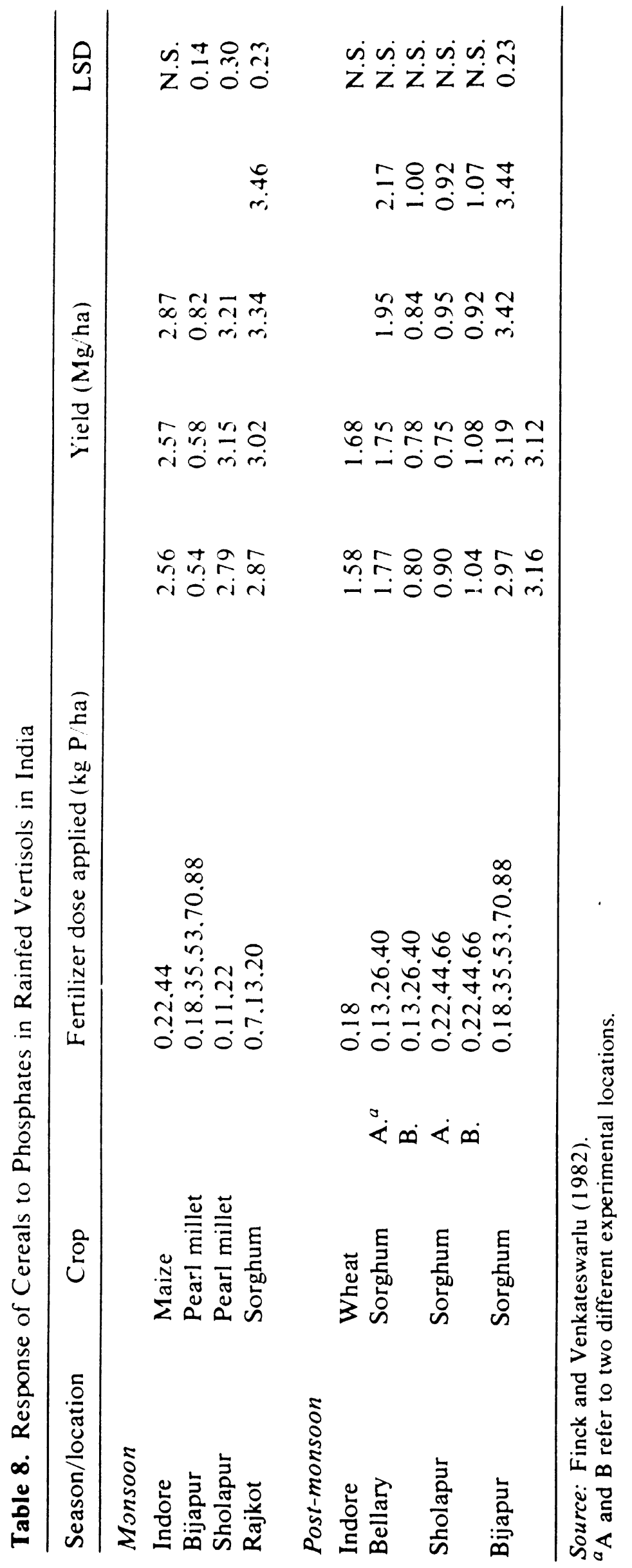


Table 9. Summary of Recommended Fertilization Strategies for Improved Management of Rainfed SAT Vertisols

1) Nitrogen

a) Short-term 'goal: Use of $\mathrm{N}$ fertilizers

Quantity: about $80 \mathrm{~kg} \mathrm{~N} / \mathrm{ha}$ in average rainfall years

$80-120 \mathrm{~kg} \mathrm{~N} /$ ha in above average rainfall years

$40 \mathrm{~kg} \mathrm{~N} / \mathrm{ha}$ in below average rainfall years

Form: Any common form of fertilizer is suitable

Method of application: Banding is more effective than broadcast or broadcast incorporation

Time of application: Basal dose +1 or 2 split applications for top-dressing

b) Long-term goal: Buildup of organic sources

i) Use of FYM and crop residues

ii) Cereal/legume intercrop or cereal-legume sequential cropping

iii) Crop or cropping systems rotation involving ground cover/green manure

2) Phosphorus

Quantity: About $15 \mathrm{~kg} \mathrm{P} / \mathrm{ha}$ if soil has $<5 \mathrm{ppm}$ of Olsen-extractable P

Form: Water-soluble $\mathbf{P}$

Method: Band application

Time: Basal

3) Zinc

$50 \mathrm{~kg} \mathrm{ZnSO}_{4}$ once in 3 or 4 years as basal

of the rainfall probabilities over short periods ( 1 week or less) have been utilized to determine the potential feasibility of dry sowing. Optimum sowing time was concluded to be just before the period showing a $70 \%$ probability of rain. Rainy season crops such as sorghum, maize (Zea mays L.), and pigeonpea have been established successfully at ICRISAT during the past 10 years using this technique. To reduce the risk of premature germination with insufficient pre-season showers, the seeds are sown quite deep, i.e. at 7 to 10 $\mathrm{cm}$. Good-quality seed beds are required with the absence of large clods to ensure good seed-soil contact and prevent the deep infiltration of water from small rain showers which may result in premature germination. Seeds of certain crops which cannot be deeply sown /e.g. small-seeded crops such as millet and setaria (Setaria italica Beauv.) | and Rhizobium-innoculated seeds such as soybeans (Glycine max (L.) Merr.) are not recommended for dry sowing as these bacteria do not appear to survive the high soil temperatures which prevail in the pre-rainy season. When it can be done, dry sowing ensures an early start of the cropping period which allows fast development of protective crop cover (with subsequent reductions in runoff and erosion, Table 6) and also makes it feasible in most years to grow a second crop on residual moisture in the post-rainy season. 
While dry sowing of the first crop allows its early establishment and successful growing of a second crop, the harvest time for the first crop may coincide with w'et weather conditions at the tail end of the rainy season. This presents a risk of damage to crops or cultivars that cannot resist such problems as molds or lodging, etc. For this reason and because it does not ratoon, maize has been more preferred as a rainy season cereal than sorghum (Kampen, 1982). Interestingly, where rainy season cropping is traditionally practiced in India, farmers sow only after the onset of the monsoon. Therefore, where dry sowing is not feasible for one reason or another, the possibility exists that sowing be done as soon as possible after commencement of the rainy season to allow most of the advantages of dry sowing to be obtained.

The two major cropping systems which were recommended by ICRISAT consist of either a sequential system of maize ( 2 rows per bed in the BBF design) followed by a chickpea ( 4 rows) as the post-rainy season crop, or an intercrop of simultaneously planted pigeonpeas (one row down the middle of the bed) and maize ( 2 rows, one on each side of the pigeonpea). Recent studies have shown that sorghum-pigeonpea intercropping is equally profitable (Figure 11). However, the regrowth of sorghum stubble may cause serious problems to the accompanying crop. In addition to these cropping systems, there exists a wide range of other combinations which not only readily fit into the scheme of improved technology but also can accomodate farmer preferences. These include sequential crops of sorghum-safflower, mungbean-sorghum, and other combinations which are discussed elsewhere (ICRISAT, 1981).

Intercropping is the preferred means of extending the cropping into the post-rainy season on these soils as it eliminates the need for a second land preparation between seasons. When required, such preparation normally consists of shallow tillage in the space between preceding crop stubble on the bed zone and re-ridging. Where the stubble ratoons and a satisfactory ratoon crop is unlikely, as for sorghum, stubble will have to be plowed under. Basal fertilizer application and sowing must be done when soil is quite moist; this requires more time than dry season preparations.

The introduction of rainy season crops in the Vertisols increases the incidence of weeds in both sequential and intercropping systems. Therefore, proper weed control measures are essential aspects of the improved technology (Kanwar et al., 1982). Normally two hand weedings during the rainy season timed 3-4 weeks and 6-8 weeks after crop emergence are sufficient for control of weeds in sorghum and maize. For intercrops (e.g. with pigeonpea), a third weeding may be needed after the harvest of cereal. Post-rainy season crops require only one weeding. Whenever possible, weeding is done as intercultivation by use of implements attached to the wheeled tool carrier. Weeding benefits have been clearly illustrated for both sequential and intercropping systems (Table 10).

With the continued use of the BBF system on ICRISAT's experimental watersheds. a clear shift has been observed in the composition of the weed 
Figure 11. Grain yields for post-rainy season sorghum. chickpea. and pigeonpea on Vertisols at ICRISAT Center after threé different use patterns during the preceding rainy season. (Average of 1978-80.) Source: Virmani e'l al. (1981).

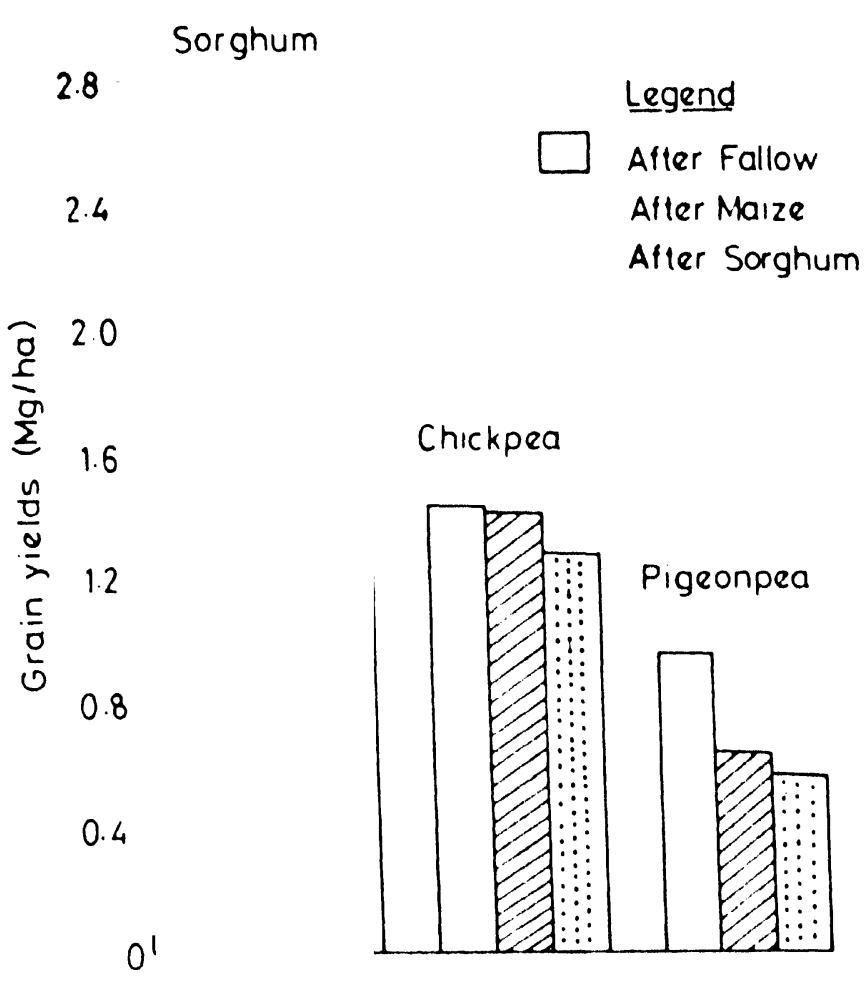

population (Shetty et al., 1982). Earlier, Amischophacelus axillaris (L.) R. Rao, and $K$. Digitaria ciliaris (Retz.) Koeler, and Dinebra retroflexa (Vahe.) Panz, all annual monocots, were the prominent weeds. Within five years from the introduction of the BBF system perennial species, primarily Cynodon dactylon (L.) Pers and Cyperus rotundus L. (both monocots) and Celosia argentea (L.) and Lagascea mollis Cav (dicots) became prevalent. Farmers control these perennial weeds by deep summer plowing in perpendicular directions once every 2 to 3 years. Since this practice would defeat the many benefits of maintaining the BBF system in place, work is now in progress on other methods to control these grasses.

Other measures of plant protection are also essential for obtaining the full benefits of improved technology as most improved cultivars are quite susceptible to pest attack, e.g. hybrid sorghum is quite susceptible to the shootfly and stemborer |Chilo partellus (Swinhoe)|.

Table 10. Effect of Different Weed Management Systems on Crop Yields in Deep Vertisols at ICRISAT Center (1980-81)

\begin{tabular}{|c|c|c|c|c|}
\hline \multirow{3}{*}{$\begin{array}{l}\text { Weed management } \\
\text { system }\end{array}$} & \multicolumn{4}{|c|}{ Crop yield (Mg/ha) } \\
\hline & \multicolumn{2}{|c|}{ Sequential cropping system } & \multicolumn{2}{|c|}{ Intercropping system } \\
\hline & Maize & Chickpea & Sorghum & Pigeonpea \\
\hline No weeding & 2.87 & 0.24 & 1.70 & 0.65 \\
\hline 2 hand weedings & 4.14 & 0.36 & 2.99 & 0.75 \\
\hline Weed-free & 5.31 & 0.51 & 3.84 & 1.14 \\
\hline
\end{tabular}

Source: Kanwar et al. (1982). 
With the low organic matter contents which are commonly encountered in cropped SAT Vertisols, the proper management of crop residues is important for both soil fertility enhancement and soil structure buildup. Unfortunately, little or no crop residue is so used by the traditional small farmer in these regions since it is preferred for use as fodder or fuel. Aside from stubble management as indicated above, intercropping of legumes with cereals offers additional advantages to improved management. An ICRISAT study on sorghum/pigeonpea intercropping indicated beneficial effects on the succeeding maize crop which were equivalent to about $15 \mathrm{~kg} \mathrm{~N} / \mathrm{ha}$. Benefits of sole cropping of pigeonpea were equivalent to about $30 \mathrm{~kg} \mathrm{~N} / \mathrm{ha}$ (Kumar Rao et al., 1983). These effects were attributed to the considerable leaf-fall which charcterizes pigeonpea as well as to its lower exhaustion of soil $\mathrm{N}$.

\section{Quantifying the Benefits of Improved Management}

Table 11 shows an operational scale comparison between yields obtained under traditional and improved systems on research watersheds (Kanwar et al., 1982). The authors concluded that there exists a synergistic effect arising from interactions between various components of improved management (Table 12). The superiority of the latter was further confirmed by follow-up economic evaluations. Ryan and Sarin (1981) estimated a rate of return of $250 \%$ on the increased working expenditure necessitated by changing from the traditional system of cultivated rainy season fallow. Limited information from village level verification trials also supports these conclusions for those areas in India where the soils and rainfall paterns conform to prescribed requirements as stated in section IV.A.2. (Walker et al., 1983).

In addition to being of direct benefit to crop yields, improved management has been much more effective than traditional management in reducing resource losses by runoff and soil erosion (Pathak et ai., 1983). On experimental watersheds during the period $1975-80$ (with a mean annual rainfall of $818 \mathrm{~mm}$ ), total runoff averaged $220 \mathrm{~mm}$, soil loss $6.64 \mathrm{Mg} / \mathrm{ha}$, and storm peak runoff rate $0.16 \mathrm{~m}^{3} / \mathrm{s} /$ ha for traditional farming as compared to 91 $\mathrm{mm}, 0.86 \mathrm{Mg} / \mathrm{ha}$, and $0.07 \mathrm{~m}^{3} / \mathrm{s} / \mathrm{ha}$ for improved BBF at $0.4 \%$ slope. This trend was consistently confirmed every year in similar comparisons during the same period (Table 13).

It may be concluded that the improved management system for Vertisols with the various components analyzed above is clearly superior to the traditional cultivated monsoon fallow system both in increasing productivity and, in so doing, enhancing the effective use and conservation of soil and water resources. The short time during which all benefits emerge (first year of implementation) is clear proof that productivity-conservation interrelationships are not always long-term in nature as is commonly reported for highly advanced farming (e.g. Larson et al., 1982; Williams, 1983). In the SAT, as in many other developing regions, the benefits of soil and water conservation-minded management are not only large but also nearly 


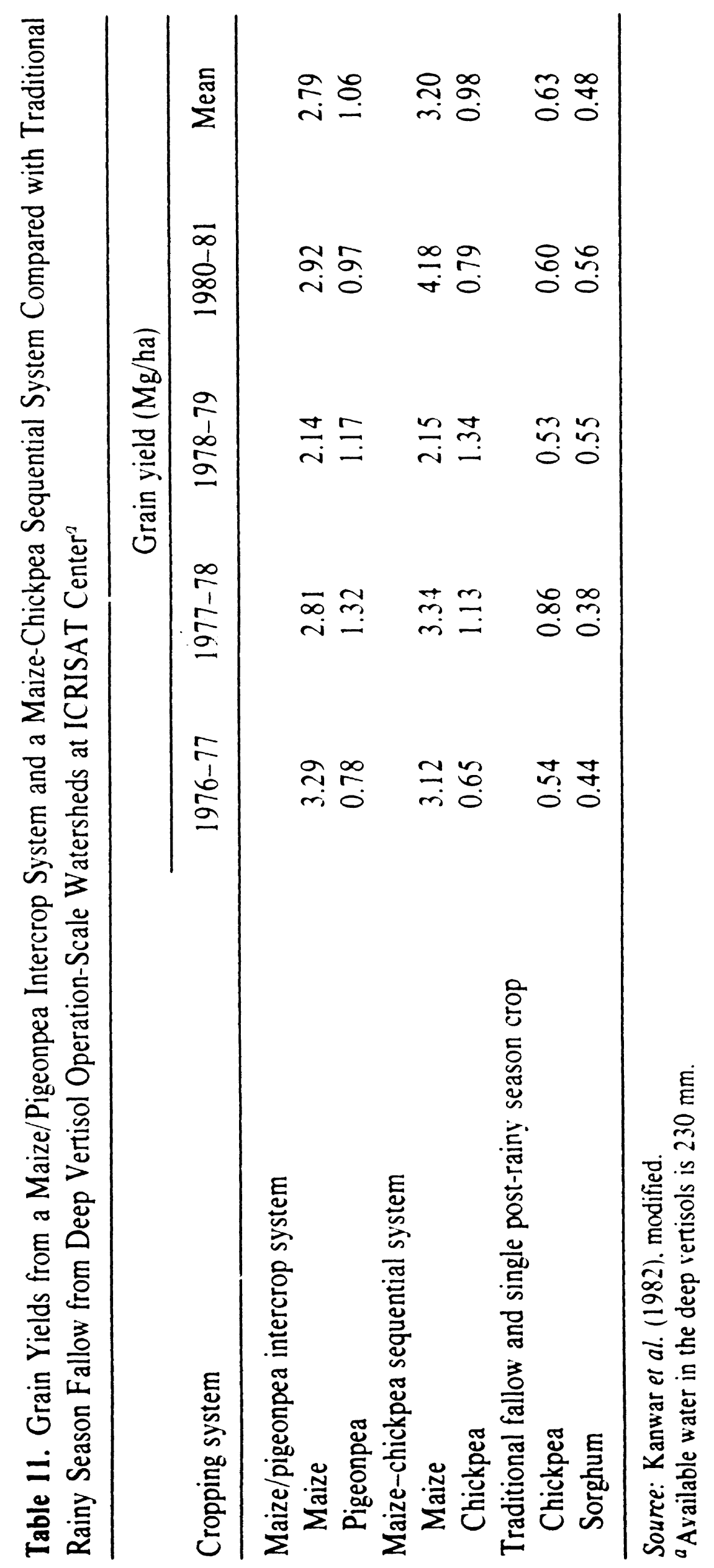


Table 12. Synergistic Effect of Variety. Soil Management, and Fertilizer Application in a Maize/Pigeonpea Intercropping System in a Vertisol at ICRISAT Center. 1976--77

\begin{tabular}{lcc}
\hline & \multicolumn{2}{c}{ Yield (Mg/ha) } \\
\cline { 2 - 3 } Treatment & Maize & Pigeonpea $^{a}$ \\
\hline & Variety:Local & \\
Check: No treatment & 0.45 & 0.32 \\
With improved soil and crop management & 0.60 & 0.61 \\
With fertilizer application & 1.90 & 0.45 \\
With improved soil-crop management & 2.61 & 0.84 \\
and fertilizer & & \\
& & \\
& Variety: & \\
& & \\
Check: No treatment & 0.63 & 0.50 \\
With improved soil and crop management & 0.96 & 0.64 \\
With fertilizer & 2.22 & 0.60 \\
With improved soil crop management & 3.47 & 0.22 \\
$\quad$ and fertilizer & & 0.47 \\
LSD (0.05) &
\end{tabular}

Source: Kanwar e'l al. (1982).

"Pigeonpea variety was the same in both cases.

immediate. Interestingly, considerable benefits have been attributed to the implementation of broad-bed concepts on poorly drained soils in developed countries as well (Morrison and Gerik, 1983). Efforts by ICRISAT to enhance the implementation of improved technology in appropriate Vertisols regions have been recently accelerated in India's SAT.

\section{B. Alfisols}

\section{Traditional Use and Management}

In contrast to Vertisols, rainfed cultivation of Alfisols is practiced only during the rainy season. The growth period for sequential cropping is extended into the post-rainy season where water is available for supplemental irrigation. For certain rainfed intercropping combinations, the growing season may extend to the end of the long-duration crop (e.g. Castor). Traditional crops include sorghum, pearl millet, finger millet, groundnuts, pigeonpea, cotton (Gossypium hirsutum L.), castor (Ricinus communis L.), green gram (Vigna rodiata (L.) Wilczek), and black gram (Vigna mungo (L.) Hepper); these are grown either as sole crops, in discrete mixtures, or as intercrops. Farmers prefer mixtures or intercropping especially in low rainfall regions because such combinations reduce the risk associated with 


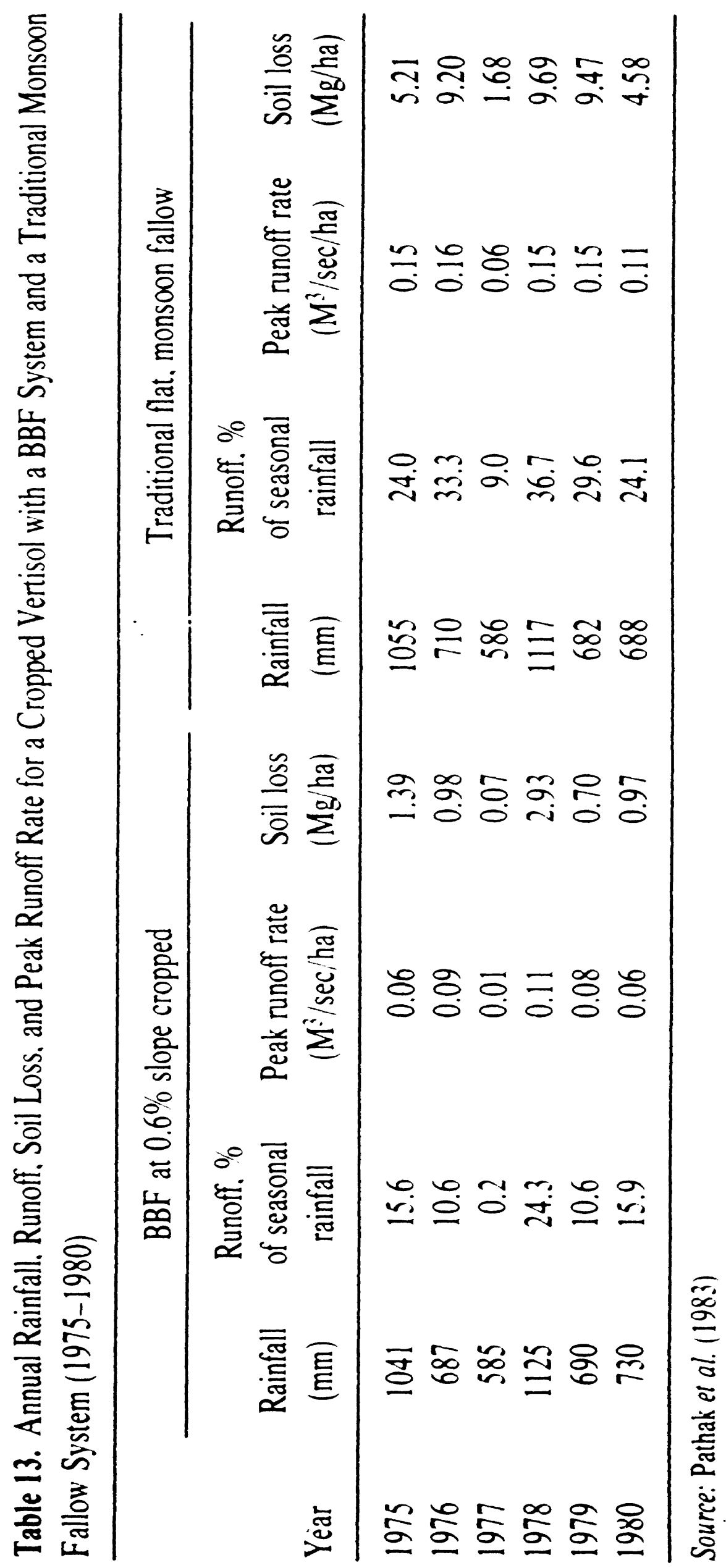


areas ranged from 10-35\% less than other areas (Pathak, unpublished report, ICRISAT, 1981). Uneven land surfaces also create problems in carrying out various agricultural operations, e.g. tillage or planting, at the proper depth. Higher germination percentages were recorded for pearl millet and sorghum in fields with proper smoothing as compared to those without (Pathak, unpublished, 1981). To alleviate the influence of such depressions it is necessary to smooth the land surface: this can be done most efficiently in the direction of envisaged cultivation.

Since high runoff is a frequent occurence in Alfisols, provisions must be made for the early and safe removal of excess runoff during the growing (rainy) season. Often, adequate crop stands are obtained only when such provisions are provided. In these soils sand deposition is a serious problem for grassed waterways. Therefore, waterways must be designed so as to allow an appropriate, but safe, velocity for disposal.

The urgency to reduce runoff from Alfisols must be tempered by the need to improve surface drainage during wet periods and by the fact that the profile's capacity for water storage is, often, very limited. The need to reduce or enhance runoff must be assessed also in light of a predetermined water resource development and use strategy. Should surface storage of excess runoff water for supplemental irrigation be determined as the feasible alternative, the system may be designed to yield and store sufficient runoff water safely for this purpose. Conversely, maximum water entry in soil should be enhanced through various ponding techniques when accessible subsurface water storage is probable.

Tied ridging (installation of furrow-dams) has been extensively tried in the African SAT as an in situ soil and water conservation system. Under certain circumstances, the system has been beneficial not only for reducing runoff and soil loss but also for increasing crop yields (Lawes 1961, 1963; ElSwaify, 1983; Dagg and Macartney, 1968). However, during high rainfall years or in years when relatively long periods within the rainy season are very wet, significantly lower yields were reported from systems with tied ridges than from graded systems which disallowed surface ponding of water (Lawes, 1963: Dagg and Macartney, 1968). Under such conditions tied ridging enhanced waterlogging, development of anaerobic conditions in the rooting zone, excessive fertilizer leaching, and water table rise in lower slope areas (Kowal, 1970). Hudson (1971) expressed serious concerns about overtopping of tied ridges and emphasized that these systems should be so designed that the ties are lower than the ridges which themselves should be graded so that excessive runoff is released along the furrow and not down the slope. Further, a support system of conventional contour terraces must be installed to cope with runoff from "exceptional" storms. Lawes (1961, 1963 and 1966) compared the performance of alternative designs with open freedraining furrows, alternate cross-tied furrows, all furrows cross-tied, and all furrows cross-tied with mulch. His results (Table 15) showed that tying of alternate furrows only or the tying of all the furrows in combination with 
ioil Management for Upurmecu . wann......

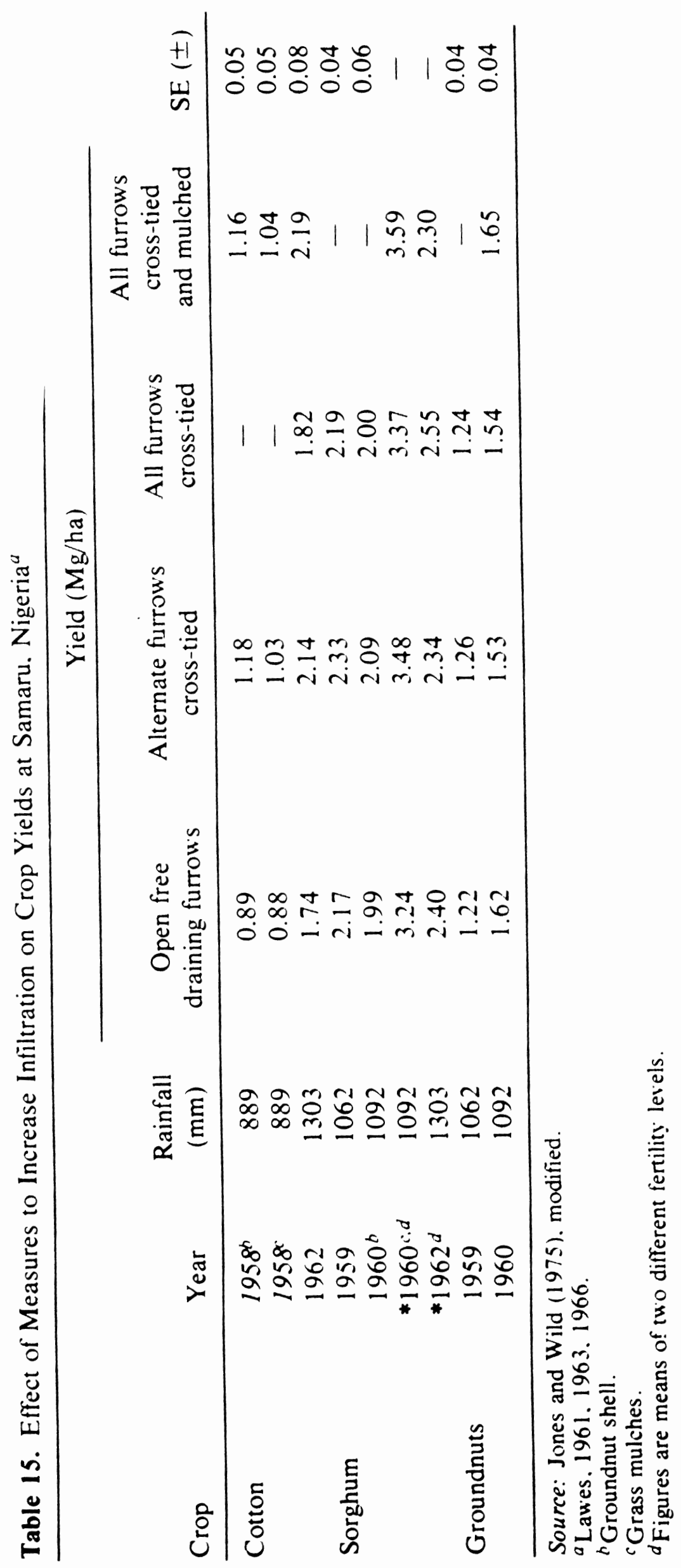


$\mathrm{Mg} / \mathrm{ha}$ of sorghum grain and $0.40 \mathrm{Mg} /$ ha of pigeonpea) to flat systems ( 3.12 and $0.45 \mathrm{Mg} / \mathrm{ha}$, respectively) (Kanwar, 1983).

There is much evidence that properly selected and imposed tillage operations, particularly primary tillage, are crucial for successful continuous cropping of SAT Alfisols. This is in contrast to the humid tropics where much success has been reported with minimum tillage use (Lal, 1977 and 1980). Intensive primary tillage of SAT Alfisols was generally found necessary for creating a favorable zone for root proliferation and for enhancing rainfall acceptance by the soil. Secondary tillage operations are necessary for seed bed preparation and weed control; herbicides are still scarcely used in the SAT. Since these soils generally undergo severe hardening during the dry season, cultivation is almost impossible to perform ahead of the rainy season. When powerful implements are utilized to allow plowing in this dry condition, the results are generally undesirable as large hard clods are created which require further intensive tillage to produce a suitable seed bed (Rawitz et al., 1981). When cultivation must await the moistening of the top soil, the effective length of the growing season is appreciably reduced and the farmer has to conduct all required operations during a very short period. Planting delays can also be harmful by allowing serious pest infestations, such as the shootfly on sorghum. Plowing at the end of the cropping season can, in some circumstances, be used to overcome these problems. Studies at Raichur (India) showed that Alfisols subjected to summer plowing had a higher rainfall intake capacity than soils not subjected to summer plowing (Hadimani and Perur 1971). Even shallow surface cultivation was found to be of advantage in helping the early rainwater soak deeply into the soil. Hadimani et al. (1982) observed that rainwater penetrated to a depth of $30 \mathrm{~cm}$ in harrowed plots but to only $15 \mathrm{~cm}$ in adjacent unharrowed plots.

Benefits of intensive tillage to crop performance were documented on many Alfisols. In Senegal, with shallow hoe cultivation the buik density of the top few centimeters of soil decreased from 1.6 to $1.4 \mathrm{~g} / \mathrm{cc}$; with tractor plowing the same benefits were effected to a depth of 10 to $30 \mathrm{~cm}$ (Charreau and Nicou, 1971: Charreau. 1972). In these soils, a decrease of $0.1 \mathrm{~g} / \mathrm{cc}$ in bulk density had a significant beneficial effect on root development and crop yields. Blondel (1965). Charreau and Nicou (1971), and Nicou and Chopart (1979) found very clear relationships between bulk densities, as reflected by porosity changes, and various indices of root development and final crop yields (Figures 12 and 13). Root density in the top 20-30 cm was closely correlated with grain yields of sorghum, groundnuts, maize, and rainfed rice in these soils (Nicou and Chopart, 1979) (Figure 14). Poulain and Tourte (1970) found the response of sorghum to deep plowing of light sandy soils to be less than to plowing of heavier soils. Nicou and Chopart (1979) showed that the proliferation of the root systems of sorghum, millet, and groundnuts were increased by from 40 to more than $200 \%$ in soil depths down to $1 \mathrm{~m}$ or more even by cultivation which did not extend deeply. Nicou 


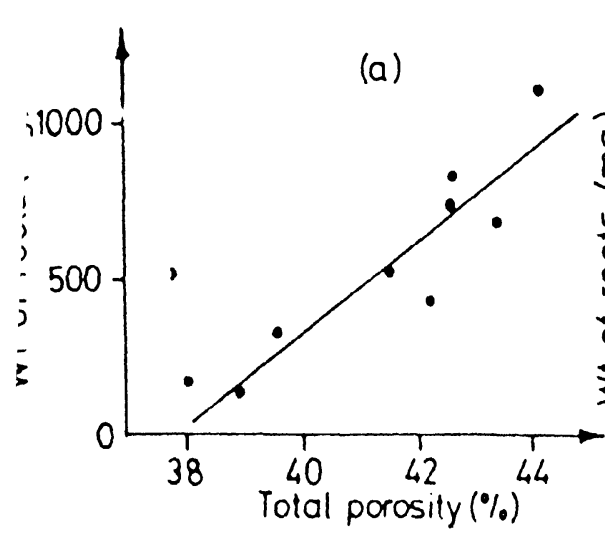

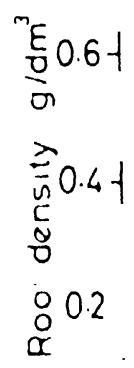

(c)

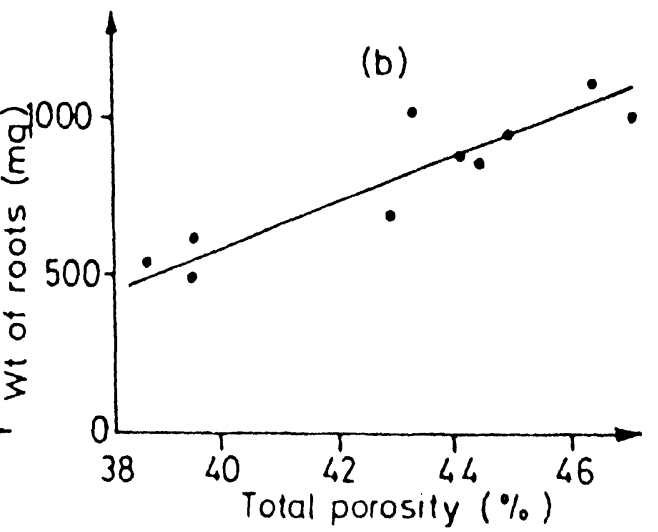

(d)

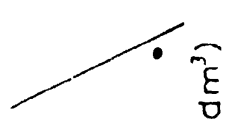

$$
0.41
$$

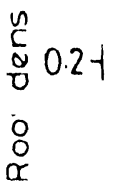

40

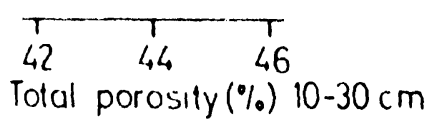

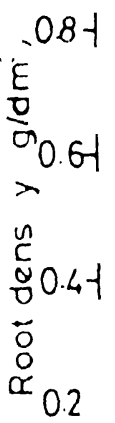

(e)

(1)

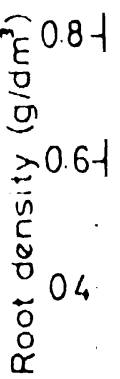

42

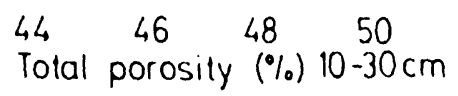

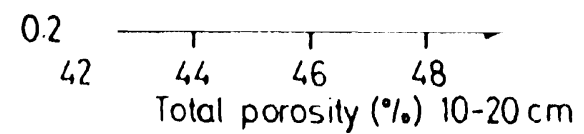

Figure 12. Relations between root growth and soil porosity at various locations in SAT West Africa. (a) Groundnuts at Bambey: (b) sorghum at Bambey: (c) sorghum at Nioro de Rip; $(d)$ maize at Sinthion, Maleme; (e) rainfed rice at Sefa: $(\Omega)$ maize at Sefa. Source: Nicou and Chopart (1979).

(1972), while confirming tillage benefits, also found little difference between crop yields obtained with different tillage depths (Table 18). These authors hypothesized that even limited tillage was sufficient to enhance rapid and deep root establishment by the crop; this allows it to escape the effects of detrimental dry spells early in the rainy season. Considerably more water losses occur by evaporation from deeply tilled Alfisols, a factor which may counteract other deep tillage benefits under limited rainfall (Rawitz et al., 1981). 

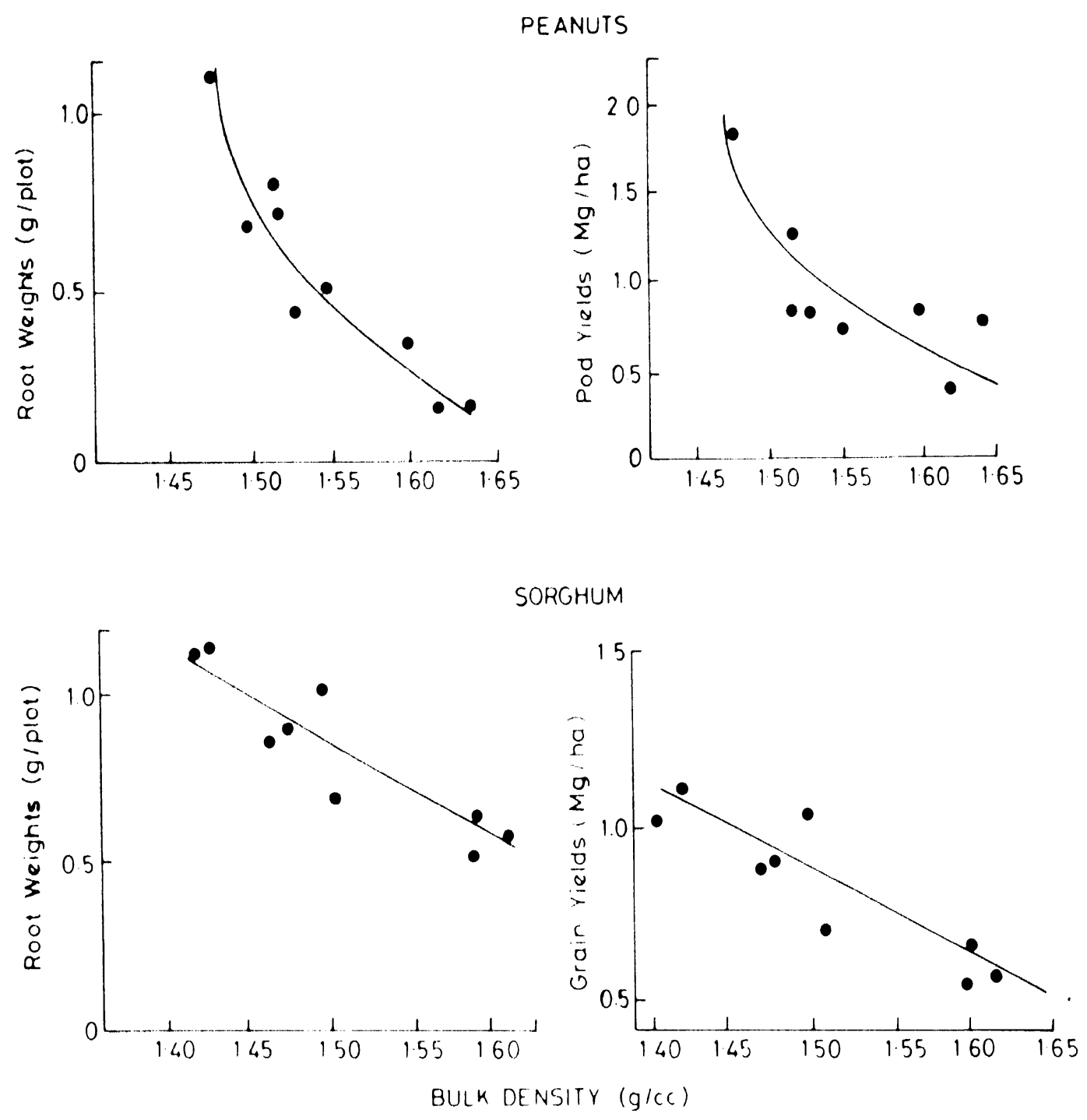

Figure 13. Relationships between bulk density, root development. and yields of peanuts and sorghum in sandy Alfisols at Bambey, Senegal. Source: Charreau and Nicou (1971).

Table 18. Effects of Superficial Tillage and Deep Plowing on Yields of Several Crops Grown on Sandy Alfisols in West Africa (Yields Reported in $\mathrm{Mg} / \mathrm{ha}$ )

\begin{tabular}{lcccc}
\hline Crops & No tillage & $\begin{array}{c}\text { Manual } \\
\text { tillage } \\
(<5 \mathrm{~cm})\end{array}$ & No tillage & $\begin{array}{c}\text { Mechanical deep } \\
\text { plowing } \\
(15-25 \mathrm{~cm})\end{array}$ \\
\hline Millet & 1.40 & 1.74 & 1.31 & 1.60 \\
Sorghum & 1.93 & 2.42 & 1.52 & 1.88 \\
Corn & 2.59 & 3.49 & 1.86 & 3.21 \\
Rice & 1.16 & 2.36 & 1.62 & 2.80 \\
Cotton & 1.34 & 1.67 & 1.30 & 1.80 \\
Peanuts & 1.45 & 1.77 & 1.62 & 1.76
\end{tabular}




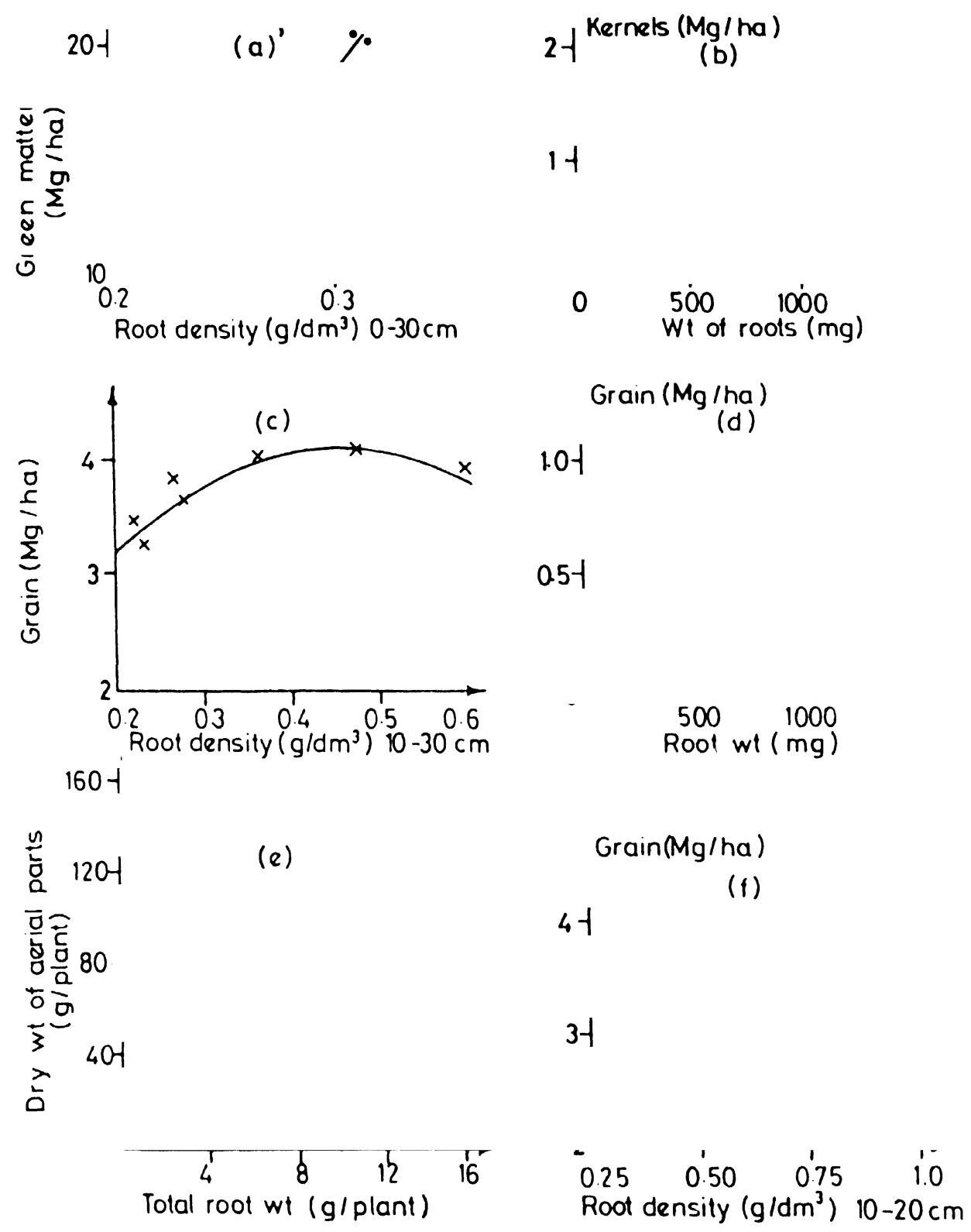

Figure 14. Relations between root development and yield for different plant species in Senegal. (a) Fallow at Bambey; (b) groundnuts at Bambey, 1964; (c) sorghum at Nioro de Rip, 1967; (d) sorghum at Bambey, 1964:(e) rainfed rice at Sefa, 1970; $(f)$ maize at Sega; 1969. Source: Nicou and Chopart (1979).

In India, Sriram et al. (1982) demonstrated relatively high benefits of deep tillage to pigeonpea and castor but not to groundnuts or a groundnutpigeonpea intercrop (Table 19). At Anantapur, deep plowing also promoted greater root development in castor and pearl millet than shallow tillage. tillage. Deep tillage increased profile moisture storage, improved yields and increased the infiltration rate from 35 to $60 \mathrm{~mm} / \mathrm{hr}$. Sree Ramulu (1972, cited by Hadimani et al., 1982) reported that pearl millet, castor, and finger millet crops in deep-tilled plots produced 12, 34 and $87 \%$ more yields, respectively, than in shallow-tilled plots. Further studies with Alfisols at a 
Table 20. Crop Responses to $50 \mathrm{~mm}$ of Supplemental Irrigation during the August, 1974 Monsoon Season Drought

\begin{tabular}{|c|c|c|c|c|c|}
\hline \multirow[b]{2}{*}{ Crop } & \multicolumn{2}{|c|}{ Grain yields ( $\mathrm{Mg} / \mathrm{ha})$} & \multirow{2}{*}{$\begin{array}{l}\text { Percent yield } \\
\text { increase from } \\
50 \mathrm{~mm} \text { of } \\
\text { supplemental } \\
\text { water }\end{array}$} & \multicolumn{2}{|c|}{ Stalk yields ( $\mathrm{Mg} / \mathrm{ha})$} \\
\hline & $\begin{array}{c}\text { No } \\
\text { supplemental } \\
\text { irrigation }\end{array}$ & $\begin{array}{c}50 \mathrm{~mm} \\
\text { of } \\
\text { water }\end{array}$ & & $\begin{array}{c}\text { No } \\
\text { supplemental } \\
\text { irrigation }\end{array}$ & $\begin{array}{l}50 \mathrm{~mm} \text { of } \\
\text { supplemental } \\
\text { irrigation }\end{array}$ \\
\hline Sorghum & 1.88 & 3.88 & 106 & 8.22 & 10.88 \\
\hline $\begin{array}{l}\text { Pearl } \\
\text { millet }\end{array}$ & 2.04 & 3.24 & 59 & 9.16 & 13.22 \\
\hline Maize & 2.96 & 5.75 & 95 & 7.58 & 8.71 \\
\hline Sunflower & 0.90 & 1.20 & 32 & - & - \\
\hline
\end{tabular}

Source: Vijayalakshmi and Sachan (1977).

increased yields of chickpea and safflower from 0.47 to 0.81 and from 0.75 to $1.05 \mathrm{Mg} /$ ha, respectively. The responses obtained for supplemental irrigation during a prolonged drought in August, 1974, are shown in Table 20. During the 1981 rainy season, good responses were also obtained to supplemental irrigation of pearl millet, sorghum, and groundnuts (Table 21). This table also shows that, as expected, the response to supplemental irrigation during 1982, a high rainfall year, was quite low. In the post-rainy season, significant responses to supplemental irrigation were obtained in both years (Table 22). Deep-rooted crops such as pigeonpea and castor responded only to larger applications so that two irrigations of $40 \mathrm{~mm}$ each were required.

\section{b. Fertility Components}

The sandy surface texture, low cation exchange capacity, and low organic matter contents of cropped SAT Alfisols require that fertilization be practiced, even under rainfed conditions, for effective crop production.

As is the case for Vertisols, nitrogen is the most limiting nutrient for cropping of SAT Alfisols. Estimates of nitrogen mineralization rates (Jones, 1973; Charreau, 1974; ICRISAT, 1979; Kausalya, unpublished data, ICRISAT, 1982 showed that more $\mathrm{NO}_{3}-\mathrm{N}$ has been mineralized after the first rains in Alfisols as compared to Vertisols, both having comparable amounts of organic matter. The amount of $\mathrm{N}$ mineralized at the begining of the rainy season was shown to depend upon the soil's organic matter content and its $\mathrm{C}: \mathrm{N}$ ratio, the intensity of the dry period before the onset of the monsoon. moisture level in the profile, and other soil characteristics. The overall levels of inorganic nitrogen in Alfisols are subject to many seasonal fluctuations. In general, tinere is a slow nitrate buildup in the topsoil during the dry season, a large but short-lived buildup at the onset of rains, and a rapid decline during the monsoon season. Other small peaks do occur during dry spells within anc 


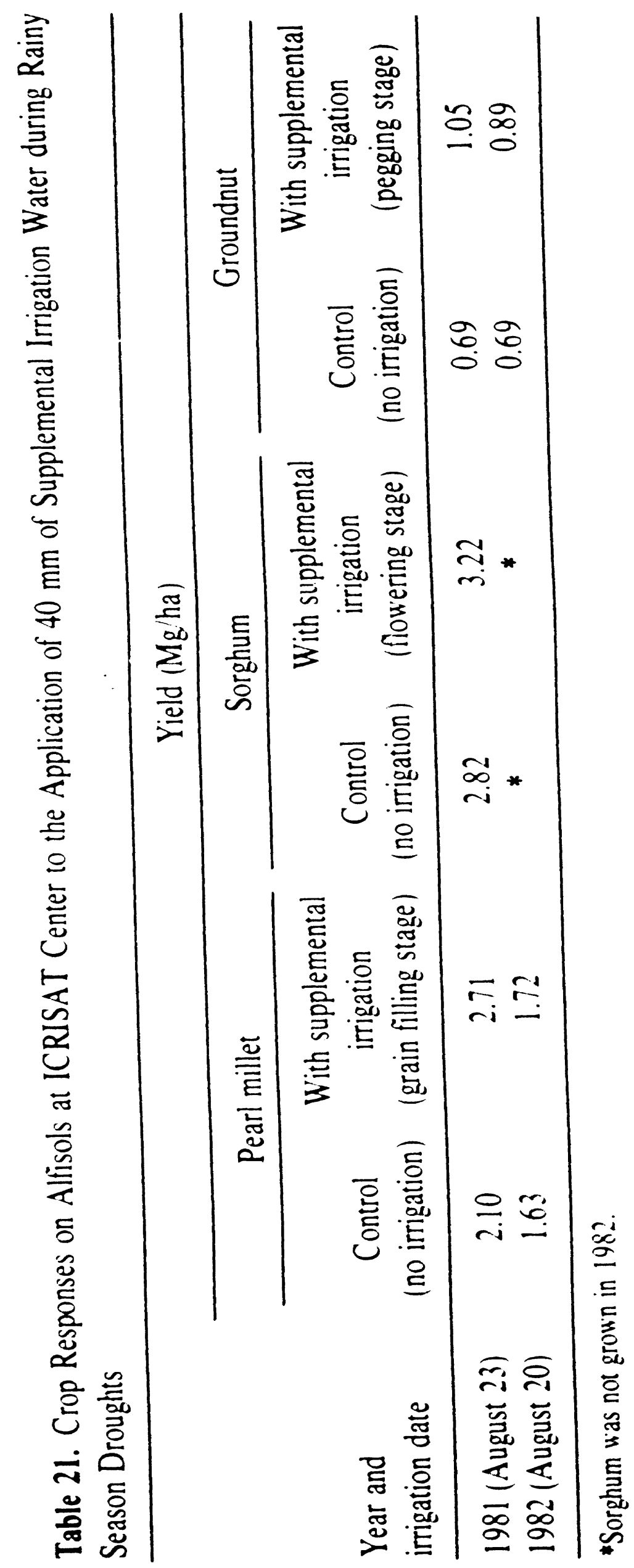




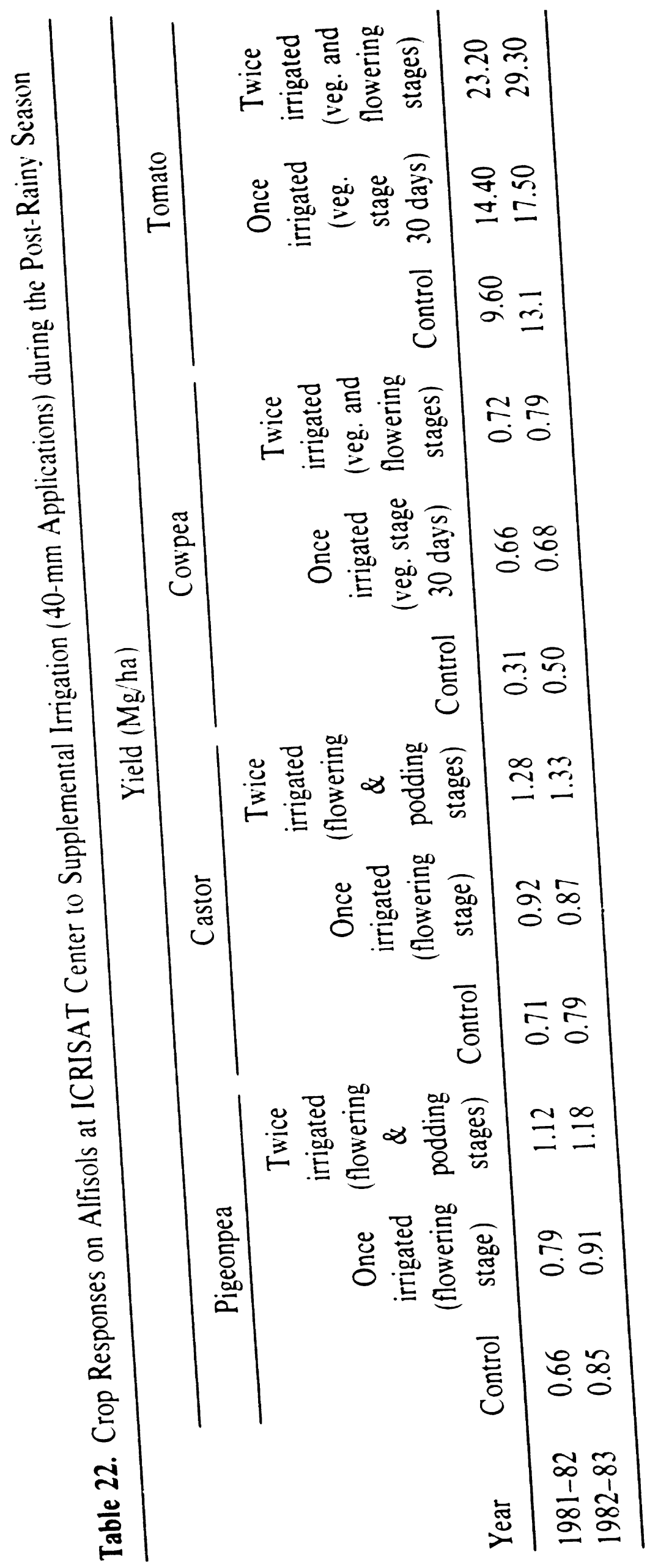




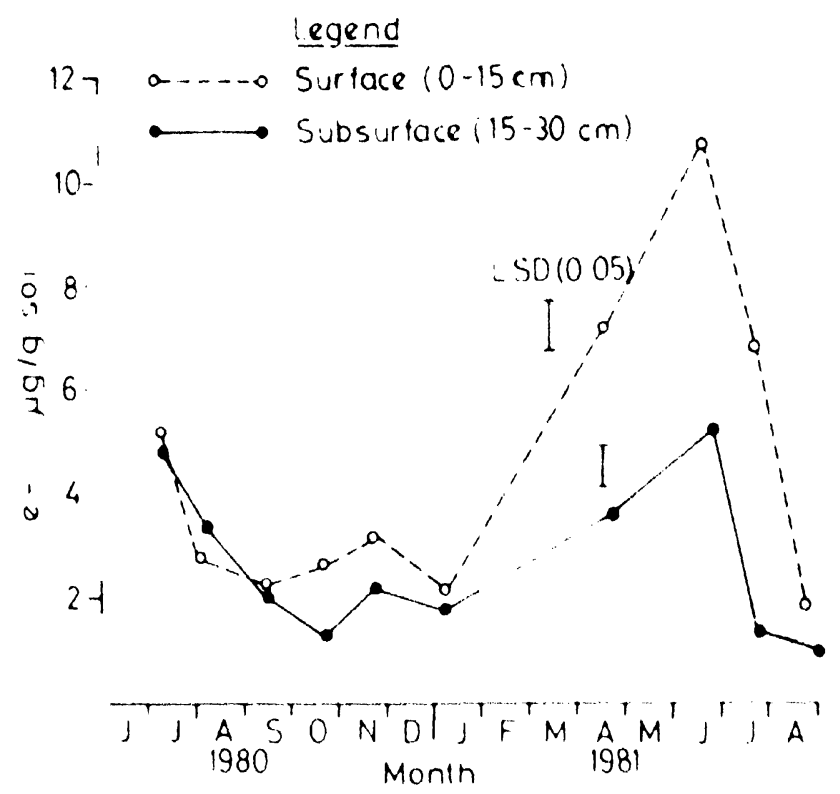

Figure 16. Seasonal fluctuations in nitrate- $N$ contents in the $0.15 \mathrm{~cm}$ and 1530 cm depths of the Patancheru soil series (a Udic Rhodustalfs) at ICRISAT (enter. Data represent averages of 4 cultivation treatments; soil was cropped with a cereal (millet or sorghum) in the rainy season (June Sept.) of each year. Somrce: Kausalya (1982).

following the monsoon season. This phenomenon was first described by Hardy (1946) and by Birch (1958, 1960) (all cited by Jones and Wild. 1975 ) in Africa and is commonly referred to as the "Birch effect." At ICRISAT Center distinctive peaks of $\mathrm{NO}_{3}-\mathrm{N}$ accumulation have been noticed. confirming the above trends. Figure 16 illustrates examples of observed seasonal fluctuations of $\mathrm{NO}_{3}-\mathrm{N}$ at two soil depths. More quantitative data are needed in this field for a full understanding of the practical significance of the development of $\mathrm{NO}_{3}-\mathrm{N}$ "flush" in these soils. With the common farming practice of sowing the crops immediately after the onset of the monsoon, effective use is made of this "flush." One major practical aim of improved management should also be to capitalize on these trends by avoiding delays in planting operations and by timing fertilizer applications accordingly.

Responses to $\mathrm{N}$ fertilization in rainfed Alfisols have been shown to depend heavily on the rainfall pattern in a given year. Good responses to applied $\mathrm{N}$ have generally been obtained in normal or high rainfall years for sorghum, millet, castor, and finger millet. But in years with intermittent droughts, excess $\mathrm{N}$ has resulted in losses of grain yield (Figure 17). As rainfall in the SAT is erratic both in quantity and distribution and Alfisols have limited water-holding capacities, it would be difficult to prescribe a generalized practice for their $\mathrm{N}$ fertilization. Kanwar and Rego (1983) proposed that, depending on the particular agroclimatic zone, a minimum quantity of $\mathrm{N}$ may be prescribed and that additional applications be based on the probability of rainfall occurrence and the risk-bearing capacities of the farmers. At ICRISAT, the application of $40-80 \mathrm{~kg} \mathrm{~N} / \mathrm{ha}$ is generally recommended with $40 \mathrm{~kg}$ as a basal dose and the remainder as top dressing applications. 


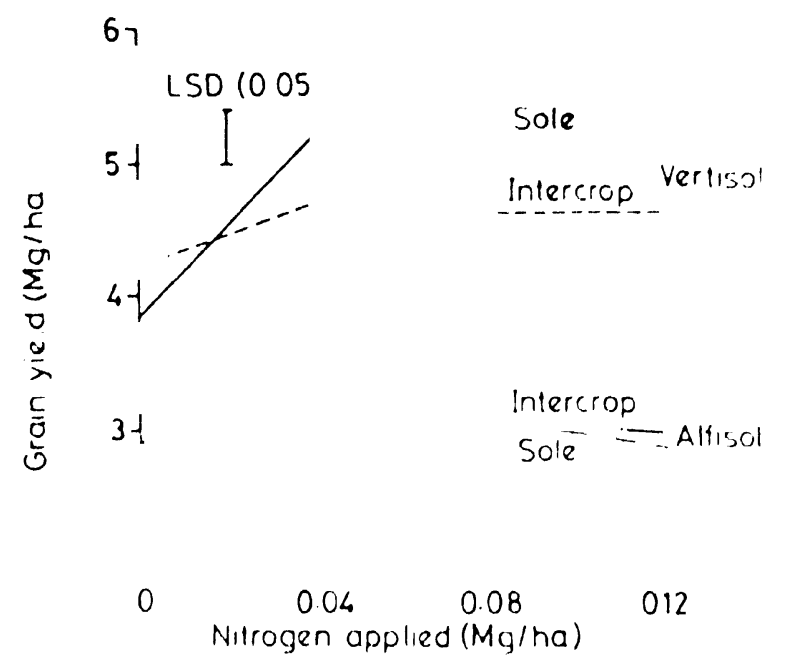

Figure 17. Sorghum response to applied nitrogen with sole and intercropping schemes on Alfisols and Vertisols at ICRISAT Center, 1979. Source: Ir RISAI (1981).

Interestingly, in normal or high rainfall years the response of sorghum (grain yield) to applied $\mathrm{N}$ was greater in Alfisols than in Vertisols (Moraghan et al., 1983) (Table 1.23). Nevertheless, the source of $\mathrm{N}$ fertilizer is much more critical for Alfisols than Vertisols. Soil depth appears to determine the importance of $\mathrm{N}$ sources. In deep Alfisols, little difference was reported among different sources for sorghum (Moraghan et al.. 1983). But in shallow Alfisols ammoniacal or organic sources are preferred since easily leachable sources, e.g. urea or $\mathrm{NO}_{3}$-salts, may be lost quickly beyond the root zone under heavy rainfall (Hong, 1983, unpublished data, ICRISAT). The method of application also has a great bearing on the efficiency of fertilizer use. Moraghan et al., (1983) have clearly shown that split banding is superior to broadcasting or broadcast incorporation in wet years. A nitrogen balance study using ${ }^{15} \mathrm{~N}$ in deep Alfisols indicated a very good fertilizer recovery as the losses, regardless of application method, were very small (Moraghan et al., 1983). At ICRISAT, similar studies are now underway in shallow

Table 23. Response of Rainy Season Sorghum (CSH-6) Grain Yield to Applied N at ICRISAT Center. during 1980 and $1981^{\circ}$

\begin{tabular}{|c|c|c|c|c|c|}
\hline \multicolumn{3}{|c|}{ Alfisols } & \multicolumn{3}{|c|}{ Vertisols } \\
\hline \multirow{2}{*}{$\begin{array}{l}\mathrm{N} \text { rate } \\
(\mathrm{kg} / \mathrm{ha})\end{array}$} & \multicolumn{2}{|c|}{ Grain yicld ( $\mathrm{Mg} / \mathrm{ha})$} & \multirow{2}{*}{$\begin{array}{l}\mathrm{N} \text { rate } \\
(\mathrm{kg} / \mathrm{ha})\end{array}$} & \multicolumn{2}{|c|}{ Grain yield $(\mathrm{Mg} / \mathrm{ha})$} \\
\hline & 1980 & 1981 & & 1980 & 1981 \\
\hline 0 & 5.23 & 1.59 & 0 & 3.38 & 2.72 \\
\hline 40 & & 3.65 & 37 & 3.90 & 3.61 \\
\hline 80 & 6.13 & 4.66 & 74 & 4.42 & 5.22 \\
\hline 120 & & 5.72 & 111 & 4.91 & 5.33 \\
\hline 160 & & 6.35 & 148 & 4.88 & 5.31 \\
\hline $\mathrm{SEM}^{h}$ & 0.18 & 0.38 & SEM & 0.18 & 0.22 \\
\hline
\end{tabular}

${ }^{a}$ Unpublished data. J.T. Moraghan. ICRISAT. 1983.

${ }^{b}$ Standard error of the mean. 
Alfisols to determine the fate of $\mathrm{N}$ applied to a sole cereal and intercropping systems involving legumes.

Phosphorus is the second most limiting nutrient in SAT Alfisols. Alfisols are low in total $\mathrm{P}$, usually containing less than $200 \mathrm{ppm}$ (Nye and Bertheux. 1957). Organic $P$ may represent $60-80 \%$ of total soil $P$ in SAT Alfisols. The representative soil at ICRISAT Center (Table 5) has a total P content of 220 ppm of which $105 \mathrm{ppm}$ is reverted $\mathrm{P}, 49 \mathrm{ppm}$ calcium-bound $\mathrm{P}$ (CA-P). 34 ppm organic P. $27 \mathrm{ppm}$ iron-bound $\mathrm{P}(\mathrm{Fe}-\mathrm{P})$, and $4 \mathrm{ppm} \mathrm{Al}-\mathrm{P}$. The P-fixing capacity of the soils is $312 \mathrm{ppm}$ (Informal communication. World Phosphate Rock Institute. Paris, February 1. 1977) which is considered relatively high (Fox. 1980).

Cereals do clearly respond to $P$ fertilization in Alfisols. At ICRISAT Center. with extractable (Olsen) $\mathrm{P}$ less than $5 \mathrm{ppm}$, sorghum responded to applications of up to $10 \mathrm{~kg} \mathrm{P} / \mathrm{ha}$ as water-soluble phosphates. Intercropped millet responded to levels of up to $5-10 \mathrm{~kg} \mathrm{P} / \mathrm{ha}$ but intercropped pigeonpea did not respond to applied $\mathrm{P}$ fertilizer in this range. Because of high $\mathrm{P}$ fixation, banding of applied fertilizer close to the crop is recommended for good response (Rao et al., 1982). The less soluble $P$ sources such as rock phosphate are not effective and not recommended in these soils (note relatively neutral $\mathrm{pH}$ values, Table 5 ). Work in various areas in India has confirmed the good response to applied $\mathrm{P}$ fertilization in Alfisols ( $\mathrm{RaO}$ and Das, 1982). Band application of $10-15 \mathrm{~kg} / \mathrm{ha}$ of $P$ above the fixation capacity of the soil is generally recommended. There are, however, conflicting reports for such mycorrhizal crops as pigeonpea since these do not display consistent responses to applied P. Research is currently underway to determine the extent to which the $P$ requirement for this crop can be satisfied through association with mycorrhizae ( $R$. Busch, unpublished report, ICRISAT, 1983).

Most SAT Alfisols contain moderate levels of available K (around 125 ppm of extractable, including exchangeable, $\mathrm{K}$ ) and high levels of total $\mathrm{K}(2$ to $3 \%)$. This is due to the abundance of primary minerals in these soils (Table 5). Therefore, responses to applied $\mathrm{K}$ fertilizers have seldom been obtained, even with the intensive cropping of high-yielding varieties of cereals (Rego, unpublished data, ICRISAT, 1977). Farmers in this region generally harvest and remove the cereal stalks for cattle feed; these contain nearly $60-70 \%$ of the total $\mathrm{K}$ in harvested plants. With continuous cropping of high-yielding varieties this practice will likely result in such rapid mining of soil $\mathrm{K}$ that deficiency may be anticipated in the future. A long-term experiment being conducted at ICRISAT has shown no clearcut $\mathrm{K}$ deficiency nor a response to $\mathrm{K}$ fertilization after three years. However, from the fourth year onward, sorghum and millet did respond to $\mathrm{K}$ applications. Potassium deficiency has been reported to be a problem in some African SAT Alfisols (Jones and Wild, 1975), further confirming the wide diversity in the characteristics of these soils.

Requirements for fertilization with secondary nutrients depend on the 
In the long term, strong clues for successful cropping and sustained productivity of Alfisols may be derived from experiences in the humid tropics and temperate semi-arid areas. These soils appear to be more amenable to management for sustained agricultural productivity in the humid tropics than in the SAT. Much success has in fact been reported with minimum tillage, generous residue inputs (e.g. mulching), and, necessarily, heavy dependence on herbicide use within the cropping systems. The abundant water supply in hese regions encourages some form of vegetative growth and substantial Jverall biological activity throughout the year. In the SAT, only certain types of vegetation sustain themselves with significant viability despite the annual ong and intense dry period, particularly on Alfisols. Selected rapidly ,rowing trees have such potential and have been recommended for inclusion vith conventional cropping systems in "agroforestry" schemes in the tropics. zropping systems which capitalize on the attributes of such trees for the ienefit of soil and farmer are currently under increasing investigation in the iAT (Lundgren and Nair, 1983).

Another strategy which has been favored for accomodating a significant nimal component involves the application of legume-ley farming on SAT IIfisols (Jones and McCown, 1983). Preliminary results indicate that this ystem, which has proved successful in the temperate regions of Australia, ppears promising when the following features are included: (i) A selfenerating legume-ley pasture for $1-3$ years grown in rotation with a cereal; i) Cattle allowed to graze native grass pastures during the wet season and :guminous pastures in the dry season; (iii) Crops are planted directly into ie pasture after it has been herbicide-killed; and (iv) Volunteer pasture :gume sward from hard seed is allowed to form an understory in the main op. In contrast to conventional cropping of Alfisols, the system allows nplementation of minimum tillage concepts. While biological feasibility spears promising, the economic feasibility of this and similar systems needs oser examination.

\section{'. Conclusions}

he Alfisols and Vertisols of the semi-arid tropics have contrasting operties and, therefoic, different management requirements under rainfed mditions.

Alfisols are well-drained soils, possess limited water storage char:teristics, and are, therefore. cropped only during the rainy (monsoon) ason. Efforts to improve management of these soils for conventional opping have succeeded in increasing productivity (crop yields) over dditional management systems but effective practices for improved soil and ater conservation remain to be formulated. This is primarily because of the treme structural instability' of these soils. Physical, fertility, and biological pects of improved management have been the subject of many investi- 
gations but no integrated set of practices can be assembled, as yet, in technologiçal packages to be confidently recommended to the small farmer. Promising trends from investigations on these aspects have been presented.

The state-of-the-art shows a much brighter picture for SAT Vertisols. These soils are heavy-textured, rich in swelling clays, slowly permeable. non-trafficable while wet and non-workable while dry, but generally possess excellent water storage and good structural stability charactersitics. Traditionally, farmers cultivate these soils only during the post-monsoon season, a practice which carries little economic risk but leaves the soil bare and unprotected from highly erosive rains during the monsoon. Improved watershed-based management approaches formulated at ICRISAT allow both rainy season and post-rainy season cropping of Vertisols in assured rainfall areas. The recommended technological improvements have had immediate and dramatic benefits over the traditional management systems. These include highly economic increases in crop yiclds, amenability to small farmers' requirements, marked reductions in soil erosion, and substantially increased water utilization. Components of these recommendations and the consequences of their implementation as "packages" for improved management of Vertisols have been analyzed.

\section{References}

Awadhwal, N.K., and Thierstein, G.E. 1983. Development of a rolling type soil crust breaker. Paper presented at the XX Annual Convention, Indian Society of Agricultural Engineers, G.B. Pant University of Agriculture and Technology. Feb. 1983, Pantnagar, India.

Binswanger, H.P., S.M. Virmani, and J. Kampen. 1980. Farming systems components for selected areas in India: Evidence from IRISAl. Res. Bull 2. International Crops Research Institute for the Semi-Arid Tropics (ICRISAI). Patancheru, A.P., India.

Biswas, T.D. 1982. Management of soil physical conditions for soil productivity. J. Indian Soc. Soil Sci. 30:427-439.

Blondel, D. 1965. Premiers éléments sur l'influence de la densité apparente du sol sur la croissance racinnaire de l'arachide et du sorgho. Ses consequences sur le rendement. Proc. OAU/STRC Symp. on the Maintenance and Improvement of Soil Fertility, Khartoum, 173-181.

Charreau, C. 1972. Problèmes posès par l'utilisation agricoles des sols tropicaux par des cultures annuelles. Agron. Trop. 27:905--929.

Charreau, C. 1974. Soils of tropical dry and dry-wet climatic areas of West Africa and their use and management. Lecture series delivered at Cornell University, Ithaca, New York.

Charreau, C. 1977. Some controversial technical aspects of farming systems in semiarid West Africa. Proc. Intl. Symp. of Rainfed Agriculture in Semi-Arid Tropics, April 17-22, 1972. Riverside, California. pp. 313-360.

Charreau, C. and F. Fauck. 1970. Mise au point sur l'utilisation agricole des sols de la région de sefa (casamance). Agron. Trop., 25:151-191. 
Charreau, C., and R. Nicou. 1971. L'amélioration du profil cultural dans les sols sableux et sablo-argileux de la zone tropicale seche ouest-africane et ses incidence agronomiques. Agron. Trop. 26:209-255, 903-978, 1183-1247.

Chatterjee, R.K., and G.S. Rathore. 1976. Clay mineral composition, genesis and classification in Madhya Pradesh. J. Indian Soc. Soil Sci. 24:144-157.

Cocheme, J., and P. Franquin. 1967. A study of the agroclimatology' of the semi-arid area, south of the Sahara in West Africa: FAO/UNESCO-WMO Interagency' project on agroclimatology'. Tech. Report. 86, Rome.

Dagg, M., and J.C. Macartney. 1968. The agronomic efficiency of the NIAE mechanized tied ridge system cultivation. Exptl. Agr. 4:279-294.

De Vos, J.H., and K.J. Virgo. 1969. Soil structure in Vertisols of the Blue Nile Clay plains Sudan. J. Soil Sci. 20:189-206.

Dhruva Narayana. V.V.. and Ram Babu. 1983. Estimation of soil erosion in India. J. Irrg. and Drainage Engineering. ASCE:109 (December issue).

Digar, S., and N.K. Barde. 1982. Morphology genesis and classification of red and laterite soils. In: Review' of soil research in India, part II, Trans. I2th Intl. Congr. Soil Sci., pp. 498-507. New Delhi, India.

El-Swaify, S.A. 1983. Conservation-effective farming systems for the semi-arid tropics. Soil physics and conservation, FSRP. ICRISAT, Patancheru, A.P., India.

El-Swaify, S.A., and E.W. Dangler. 1977. Erodibilities of selected tropical soils in relation to structural and hydrologic parameters. SCSA Special Publication No. 21. pp. 105 114. Soil Conservation Society of America, Ankeney, Iowa.

El-Swaify. S.A. and E.W. Dangler. 1982. Rainfall erosion in the tropics: A state-ofthe-art. Special Publication No. 43, pp. 1-25. Soil Science Scciety of America, Madison, Wisconsin, USA.

El-Swaify, S.A., E.W. Dangler, and C.L. Armstrong. 1982. Soil erosion by water in the tropics. Research Extension Series 024. Univ. of Hawaii. Institute of Tropical Agriculture and Human Resources. Honolulu. Hawaii.

El-Swaify, S.A., S. Sinanuwong. A. Daud, and A. Tengah. 1977. Managing saline waters for irrigation. Proc. Intl. Conf., Texas Tech. Univ., Lubbock. Tex. pp. $358-375$.

FAO. 1974. Improving productivity' in law rainfall area. Rome, Italy.

FAO/UNESCO, 1974 78. Soil maps of the world. UNESCO. Paris.

Finck. A. 1961. Classification of Gezira clay soil. Soil Sci. 92:263-267.

Finck. A., and J. Venkateswarlu. 1982. Chemical properties and fertility management of Vertisols. Vertisols and rice soils of the tropics. Proc. 12th Intl. Congr. Soil Sci.. New Delhi, India. pp. 61-79.

Fox, R.L. 1980. Soils with variable charge: Agronomic and fertility aspects. In: Theng (1980). pp. 195-224.

Hadimani, A.S., B.R Hegde, and T. Satyanarayan. 1982. Management of red soils. Review of soil research in India, part II. Trans. 12th Intl. Congr. Soil Sci., New Delhi, India. pp. 689-700.

Hadimani, A.S.. and N.G. Perur. 1971. Measurement of infiltration rate in some of the soils of the Tungabhadra Project Area. J. Indian Soc. Soil Sci. 19:231-235.

Hudson, N.W. 1971. Soil conservation. Cornell University Press, Ithaca, New York. 
ICRISAT (International Crops Research Institute for the Semi-Arid Tropics). 1978. Ann. Rept. 1977-78. Patancheru P.O.. AP. India.

ICRISAT (International Crops Research Institute for the Semi-Arid Tropics). 1979. Ann. Rept. 1977-79. Patancheru P.O.. AP. India.

ICRISAT (International Crops Research Institute for the Semi-Arid Tropics). 1980. Ann. Rept. 1979-80. Patancheru P.O.. AP. India.

ICRISAT (International Crops Research Institute for the Semi-Arid Tropics). 1981. Ann. Rept. 1980-81. Patancheru P.O.. AP. India.

ICRISAT (International Crops Research Institute for the Semi-Arid Tropics). 1981a. Report of work, on-farm research, farming systems research program. ICRISAT, Patancheru P.O., AP. India.

ICRISAT (International Crops Research Institute for the Semi-Arid Tropics). 1982. Ann. Rept. 1981-82. Patancheru P.O., AP. India.

ICRISAT (International Crops Research Institute for the Semi-Arid Tropics). 1982a. Research highlights 1982. Patancheru P.O.. AP. India.

ICRISAT (International Crops Research Institute for the Semi-Arid Tropics). 1983. The animal-drawn whecled tool carrier. ICRISAT Information Bulletin 8 . Patancheru, AP, 502 324, India.

Jewitt, T.N., R.D. Law, and K.J. Virgo. 1979. Vertisol soils of the tropics and subtropics: their management and use. Outlook on Agriculture 10:33 43.

Jodha. N.S. 1979. Some dimensions of traditional farming systems in semi-arid tropical India. Paper presented at the workshop on Socio-Economic Constraints to Development of Semi-Arid Tropical Agriculture. ICRISAT, Hyderabad, India. February, 19-23, 1979.

Jodha, N.S. 1980. Intercropping in traditional farming systems. J. Development Studies 16:427-442.

Jones. M.J. 1973. The organic matter content of the savana soils of West Africa. J. Soil Sci. 24:42-53.

Jones, M.J., and A. Wild. 1975. Soils of the west African Savanna. CAB, Tech. Communication No. 55. Commonwealth Agricultural Bureau. LAB Harpenden. U.K.

Jones, R.K., and R.L. McCown. 1983. Research on a no-till, tropical legume-ley farming strategy. Research report S/10. Division of Tropical Crops and Pastures, CSIRO, Townsville, Australia.

Kampen, J. 1979. Watershed management and technology transfer in the Semi-Arid tropics. Proc.Intl. Symp. on Development and Transfer of Technology'. ICRISAT, Patancheru P.O.. AP, India. pp. 111-120.

Kampen, J. 1982. An approach to improved productivity on deep Vertisols. ICRISAT Information Bulletin II, Patancheru P.O., AP. India.

Kampen, J., J. Hari Krishna, R.C. Sachan, and P.N. Sharma. 1974. Soil and water conservation and management in farming systems research for the semi-arid tropics. Paper presented at the International Workshop on Farming Systems, ICRISAT, Hyderabad, India. November 18-21, 1974.

Kampen, J., and J.R. Burford. 1980. Production systems soil-related constraints and potentials in the semi-arid tropics with special reference to India. Priorities for Alleviating Soil Related Constraints to Food Production in the Tropics Symposium Proceedings, IRRI Los Banos, Laguna, Philippines. pp. 141-145.

Kanwar, J.S. 1979. Research at ICRISAT - an overview. Proc. Inaugural Symp. on 
tropics prospects and retrospect. Proc. Intl. Symp. on Development and Transfer of Technology. ICRISAT, Patancheru P.O., AP. India.

Rao, A.C.S., and S.K. Das. 1982. Soil fertility management and fertilizer use in dryland crops. In A decade of dryland agriculture research in India (1971-80). pp. 120-139. All India Co-ordinated Research Project for Dryland Agriculture, Hyderabad, India.

Rao, K.V., T.J. Rego, K.L. Sahrawat, and J.R. Burford. 1982. Responsiveness of pigeonpea (Cajanus cajan (L) Millsp.) to fertilizer phosphorus. Abstract No. 416 in Abstracts of Voluntary Papers, TRans. 12th Intl. Congr. Soil Sci., New Delhi. India.

Rastogi, B.K., Y.V.R. Reddy, and V. Annamalai. 1982. Economic dimensions of dry farming technology. In: A decade of dryland agriculture research in India (197180). pp. 181-198. All India Co-ordinated Research Project for Dryland Agriculture, Hyderabad, India.

Rawitz, E., W.B. Hoogmoed, and Y. Morin. 1981. Development of criteria and methods for improving the efficiency of soil management and tilling operations with special reference to arid and semi-arid regions: Final Report, Faculty of Agriculture, The Hebrew University, Rehovot, Israel.

Reddy, S.J., and Sardar Singh. 1981. Climate and soils of the semi-arid tropical regions of the world. Paper presented at the summer institute on "Production Physiology of Dryland Crops," Andhra Pradesh Agricultural University. Rejendranagar, Hyderabad, India, May 11-June 5, 1981.

Rego, T.J., J.T. Morghan, and Sardar Singh. 1982. Some aspects of soil nitrogen relating to double cropping of "deep" Vertisols in the SAT. Trans. 12th Intl. Congr. Soil Science, Vol. 6, Jan 8-16, 1982. New Delhi, India, Jan. 8-16, 1982. p. 486.

Roy, B.B., and N.K. Barde. 1962. Some characteristics of the Black Soils of India. Soil Sci. 93:142-147.

Russell, M.B. 1980. Profile moisture dynamics of soil in Vertisols and Alfisols. Proc. Intl. Workshop on the Agroclimatology' Research Needs of the SAT. Hyderabad. India, Nov. 22-24, 1978. pp. 75-78.

Ryan. J.G. 1974. Socio-economic aspects of agricultural development in the semiarid tropics. ICRISAT, Econ. Prog. Occasional Paper 6. Patancheru. AP. India.

Ryan, J.G., and Binswanger, H.P. 1979. Socio-economic constraints to agricultural development in the semi-arid tropics and ICRISAT's approach. Proc. Symp.on Development and Transfer of Technology. ICRISAT, Patancheru. AP. India.

Ryan. J.G. and Krishnagopal, C. 1981. Assessing the economics of water harvesting and supplementary irrigation: A simulation approach. Seminar paper. Economics Program, ICRISAT, Patancheru, A.P., India.

Ryan, J.G. and Sarin, R. 1981. Economics of technology options for deep Vertisols in the relatively assured rainfall regions of the Indian Semi-arid tropics. In Seminar on Management of Deep Black Soils, ICAR/ICRISAT, New Delhi. India.

Ryan, J.G. M. von Oppen., K.V. Subrahmanyam, and M. Asokan, 1974. Socioeconomic aspects of agricultural development in the semi-arid tropics. International Workshop on Farming Systems. ICRISAT, Patancheru, AP, India. November, 1979.

Sanchez. P.A. 1976. Properties and management of soils in the tropics. John Wiley, New York.

Sanghi, N.K. and S.B.P., Rao, 1982. Operational research in dryland agriculture. In: 
A decade of dryland agriculture research in India (1971-80). pp. 212-231. All India Co-ordinated Research Project for Dryland Agriculture. Hyderabad. India.

Shetty. S.V.R.. B.A. Krantz, and S.R. Obien. 1977. Weed research needs of the small farmers. Proc. Weed Sci. Conf. and Workshop. Indian Soc. of Weed Sci., APAU, Hyderabad, A.P.. India, Jan. 17-21, 1977. pp. 47-60.

Shetty, S.V.R.. M.M. Sharma, S.L.N. Reddy, and A.S. Ram. 1982. Some factors affecting crop-weed balance in the semi-arid tropics: studies on weed emergence. Agron. and Weed Sci. Progress Report No. 7, FSRP. ICRISAT, Patancheru P.O.. AP. India.

Sivakumar, M.V.K., and S.M. Virmani. 1979. Use of agroclimatic analysis in crop planning for semi-arid tropics. Paper presented at the Symposium on Plant Responses to Water Availability. I.A.R.I., New Delhi, India, Feb. 22-24. 1979.

Soil Survey Staff. 1975. Soil taxonomy. A basic system of soil classification for making and interpreting soil surveys. U.S.D.A. Handbook 4.36 .

Soman. P.. J.M. Peacock, and F.R. Bidinger. 1983. A field technique for screening seedling emergence in Pearl millet and sorghum. Exptl. Agr. (submitted).

Sriram, C., G.C. Yadav, P.D.. Gupta, and J.S. Atwal. 1982. Tillage and seeding practices relevant to drylands. In: A decade of dryland agriculture research in India (1971-80). All India Co-ordinated Research Project for dryland Agriculture, Hyderabad, India: 140-152.

Stace, H.C.T., G.D. Hubble, R. Brewer, K.H. Northcote, J.R. Sleeman, M.J. Mulcahy, and E.G. Hallsworth. 1968. A handbook of Australian soils. Rellim Technical Publication Glenside, South Africa.

Swindale. L.D. 1982. Distribution and use of arable soils in the semi-arid tropics. In: Managing Soil Resources, Plenary' Session Papers, Trans. I2th Intl. Congr. Soil Sci., New Delhi. pp. 67-100.

Theng, B.K.G. (Editor). 1980. Soils with variable charge. New Zealand Soc. Soil Sci., Soil Bureau, Department of Scientific and Industrial Research. Private Bag. Lower Hutt (448 pp).

Thompson, B. 1965. The climate of Africa. Oxford University Press, London.

Troll, C. 1965. Seasonal climates of the Earth. In: World maps of climatology, E. Rodenwaldt and H. Jusatz, eds. Springer-Verlag. Berlin.

Venkateswarlu, J. 1979. Management of soil fertility in black soils. Seminar on Management of Black Soils, Univ. Agr. Sciences, Dharwar, India.

Venkateswarlu, J. 1980. Proc. Indian (FAO/Norway) Seminar on Maximising Fertiliser Use Efficiency', New Delhi.

Vijayalakshmi, K., and R.C. Sachan. 1977. Use and application of supplemental water in rainfed agriculture. Paper presented at a Training Programme for Agricultural Officers from Selected Drought Prone Area Project Districts, ICRISAT, Patancheru, AP, India.

Virmani, S.M. 1980. Climatic approach for transfer of farming systems technology in the semi-arid tropics. Proc. Symp. on Development and Transfer of Technology, ICRISAT, Patancheru P.O., AP, India. pp. 93-102.

Virmani, S.M., M.V.K. Sivakumar, and S.J. Reddy. 1978. Rainfall probability estimates for selected locations of semi-arid India. ICRISAT Res. Rept. 1, Patancheru, A.P., India.

Virmani, S.M., M.V.K. Sivakumar, and S.J. Reddy. 1980. Climatological features of the SAT in relation to the farming systems research program. Proc. Intl. Workshop 
on the Agroclimatological Research Needs of the Semi-Arid Tropics. Hy, India, Nov. 22-24, 1978, pp. 5-16.

Virmani, S.M., R.W. Willey, and M.S. Reddy. 1981. Problems, prospe technology for increasing cereal and pulse production from deep black soil Seminar on Management of Deep Black Soils for Increased Produ, Cereals, Pulses and Oilseeds. New Delhi. pp. 21-36.

Walker, T.S., J.G. Ryan, K.G. Kshir Sagar, and R. Sarin. 1983. The econı deep Vertisol technology options: Implication for design testing and I Seminar on Technology Options and Economic Policy for Dryland Agr ICRISAT, Patancheru. P.O.. AP. India, Aug. 22-24, 1983.

Williams, J.R. 1983. The physical components of the EPIC (Erosion Pror Impact Calculator) MOdel. Proc. International Conference on Soil Eros Conservation. Honolulu. Hawaii. Jan. 16-22, 1983. 